\title{
Maximum glacier extent of the Penultimate Glacial Cycle in the Upper Garonne Basin (Pyrenees): new chronological evidence
}

\author{
Marcelo Fernandes ${ }^{1}$ (D) Marc Oliva ${ }^{2} \cdot$ Gonçalo Vieira $^{1} \cdot$ David Palacios $^{3} \cdot$ José María Fernández-Fernández $^{1}$. \\ Magali Delmas ${ }^{4} \cdot J^{\prime}$ lia García-Oteyza ${ }^{2} \cdot$ Irene Schimmelpfennig ${ }^{5} \cdot$ Josep Ventura $^{2} \cdot$ ASTER Team $^{5}$
}

Received: 5 August 2021 / Accepted: 30 September 2021 / Published online: 23 November 2021

(c) The Author(s), under exclusive licence to Springer-Verlag GmbH Germany, part of Springer Nature 2021

\begin{abstract}
The Upper Garonne Basin included the longest glacier in the Pyrenees during the Late Pleistocene. During major glacial advances, the Garonne palaeoglacier flowed northwards along $~ 80 \mathrm{~km}$ from peaks of the axial Pyrenees exceeding 2800$3000 \mathrm{~m}$ until the foreland of this mountain range at the Loures-Barousse-Barbazan basin (LBBb), at 420-440 m. Here, the palaeoglacier formed a terminal moraine complex that is examined in this work. Based on geomorphological observations and a 12-sample data set of ${ }^{10} \mathrm{Be}$ Cosmic-Ray Exposure (CRE) ages, the timing of the maximum glacial extent was constrained as well as the onset of the deglaciation from the end of the Last Glacial Cycle (LGC). Chronological data shows evidence that the external moraines in this basin were abandoned by the ice at the end of the Penultimate Glacial Cycle (PGC) and the onset of the Eemian Interglacial, at 129 ka. No evidence of subsequent glacial advances or standstills occurred during the LGC in this basin were found, as the few existing datable boulders provided in the internal moraine showed inconsistent ages, thus probably being affected by post-glacial processes. The terminal basin was already deglaciated during the global Last Glacial Maximum at 24-21 ka, as revealed by exposure ages of polished surfaces at the confluence of the Garonne-La Pique valleys, $13 \mathrm{~km}$ south of the entrance of the LBBb. This study introduces the first CRE ages in the Pyrenees for the glacial advance occurred during the PGC and provides also new evidence that glaciers had already significantly shrunk during the LGM.
\end{abstract}

Keywords Central Pyrenees · Upper Garonne Basin · Penultimate Glacial Cycle · Cosmic-ray exposure dating · Moraines · Polished bedrock

ASTER Team-Consortium: Georges Aumaître, Karim Keddadouche.

This article is part of a Topical Collection in Environmental Earth Sciences on Earth Surface Processes and Environment in a Changing World: Sustainability, Climate Change and Society, guest edited by Alberto Gomes, Horácio García, Alejandro Gomez, Helder I. Chaminé.

Marcelo Fernandes

marcelo.fernandes@live.com

1 Centre for Geographical Studies, Instituto de Geografia E Ordenamento Do Território, Universidade de Lisboa, Rua Branca Edmée Marques, 1600-276 Lisbon, Portugal

2 Department of Geography, Universitat de Barcelona, Barcelona, Catalonia, Spain

3 Department of Geography, Universidad Complutense de Madrid, Madrid, Spain

4 UMR 7194, HNHP, Université de Perpignan Via Domitia, Perpignan, France

5 Aix-Marseille Université, CNRS, IRD, INRAE, Coll. France, UM 34 CEREGE, Aix-en-Provence, France

\section{Introduction}

High and middle mountain landscapes in mid-latitude ranges have been mostly shaped by glaciers during Pleistocene glacial cycles. Large valleys, glacial cirques, truncated spurs, hanging valleys (large-scale erosional landforms) and till or moraines (accumulation landforms) constitute the legacy of the past glaciations in the highest massifs (Benn and Evans 2010). Such invaluable glacial footprints can provide a better understanding of past environmental and climatic changes (Pearce et al. 2017).

The widespread glacial features existing in mid-latitude and Mediterranean mountains have been increasingly used to reconstruct the timing, magnitude and extent of the glacial oscillations during past glacial cycles (Ehlers et al. 2011; Adamson et al. 2013). The study of glacial advances and retreats has mostly focused on the Late Pleistocene (or Last Glacial Cycle, LGC), from the end of the Eemian Interglacial (129-114 ka) to the Holocene (11.7 ka to present; 
Dahl-Jensen et al. 2013; Rasmussen et al. 2014). Glacial studies have resulted in an increase in the number and accuracy of regional and global palaeoclimate records, which generally show a good coupling between cold phases and glacial advances (Bernal-Wormull et al. 2021; GonzálezSampériz et al. 2006; Morellón et al. 2009; Lisiecki and Raymo 2005; Rasmussen et al. 2014). In the Pyrenees, where this research focuses on, currently available data indicate that the most extensive Pyrenean glaciation of the Late Pleistocene occurred prior to the global Last Glacial Maximum (gLGM: 26-19 ka; Clark et al. 2009). This outermost stadial position (local Last Glacial Maximum; ILGM) was reached not just once, but several times between MIS 5b (or MIS 4) and MIS 3 (Fig. 1a; Mardones and Jalut 1983; Andrieu et al. 1988; García-Ruiz et al. 2003, 2013; Lewis et al. 2009; Pallàs et al. 2010; Delmas et al. 2011; Turu et al. 2016; Sancho et al. 2018; Tomkins et al. 2018; Synthesis in
Delmas et al. 2021a). The dimensions of Pyrenean glaciers at the time of the gLGM are well established in the eastern part of the range, where ${ }^{10} \mathrm{Be},{ }^{36} \mathrm{Cl}$ and Schmidt hammer exposure ages have been obtained from boulders embedded in moraines and from ice-scoured rock steps protruding from valley floors (Fig. 1a; Pallàs et al. 2006, 2010; Delmas et al. 2008; Palacios et al. 2015a; Andrés et al. 2018; Tomkins et al. 2018; Synthesis in Delmas et al. 2021b). By contrast, in the westernmost valleys of the Pyrenees, glacier dimensions at the time of the gLGM remain imprecisely defined, because age constraints are mainly provided by glaciolacustrine deposits (Andrieu 1987 1991; Andrieu et al. 1988; Jalut et al. 1988; Montserrat 1992; Reille and Andrieu 1995; García-Ruiz et al. 2003; Synthesis in Delmas et al. 2021b). Besides, other periods of glacial advance and retreat during Termination I are also well-known for northern and southern valleys (Copons and Bordonau 1996; Pallàs et al. 2006,

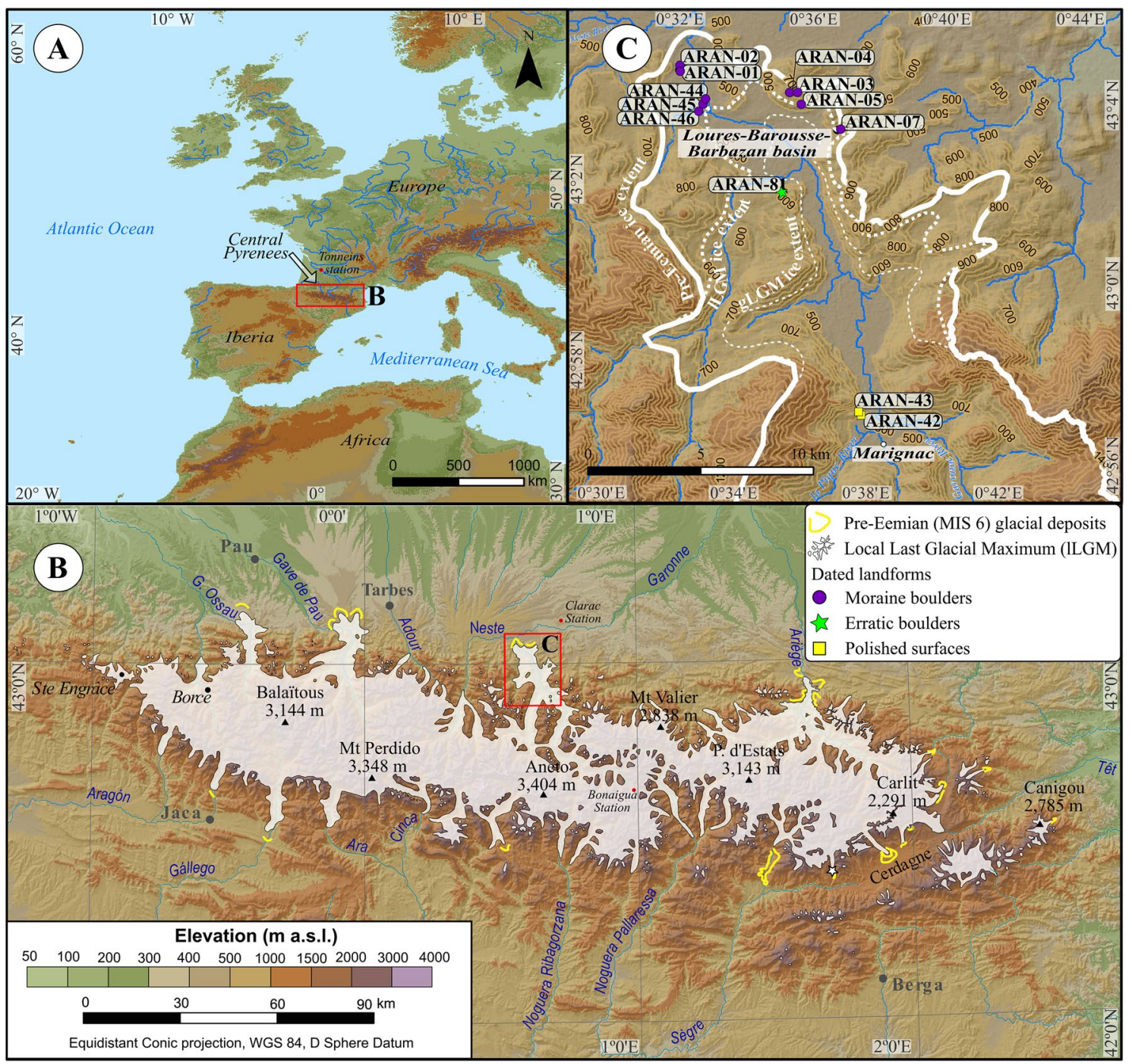

Fig. 1 Location of the terminal basin of the Loures-Barousse-Barbazan $(\mathbf{C})$ in the Pyrenees $(\mathbf{B})$ and Europe (A) 
2010; Delmas et al. 2008, 2011; Palacios et al. 2015a,b, 2017; Crest et al. 2017; Andrés et al. 2018; Tomkins et al. 2018; Fernandes et al. 2021; Oliva et al. 2021; Reixach et al. 2021).

Middle Pleistocene glaciations in the Pyrenees remain poorly documented (Fig. 1a; Synthesis in Delmas et al. 2021a). Most chronological evidence concerning ice-margin fluctuations prior to the Late Pleistocene glacial cycle is known thanks to U-Th ages in cave systems of limestone massifs (Bakalowicz et al. 1984; Quinif and Maire 1998; Sorriaux et al. 2016) and TCN profiles, OSL, ESR ages on glaciofluvial terraces (Turu and Peña-Monné 2006; Turu et al. 2007; Lewis et al. 2009; García-Ruiz et al. 2013; Delmas et al. 2015, 2018). Only one ${ }^{10} \mathrm{Be}$ exposure age at $133.9 \pm 5.3 \mathrm{ka}$ has been obtained from an erratic boulder abandoned by the Ariège Glacier at Caraybat (Delmas et al. 2011). This age also validates the post-depositional weathering criteria to differentiate those glacial deposits from older than MIS 5e and MIS 5d-MIS 2 (Gourinard 1971; Hubschman 1975, 1984; Hétu and Gangloff 1989; Gangloff et al. 1991; Hétu et al. 1992; Calvet 1996).

During the last two glacial cycles, the Central Pyrenees included large ice fields from where composite glaciers flowed downvalley for several tens of $\mathrm{km}$ forming piedmont features in the northern foreland and valley glaciers in the southern slope (Fig. 1B). The Upper Garonne Valley hosted the longest Pyrenean palaeoglacier, with an ice tongue following northwards for $\sim 80 \mathrm{~km}$ down to the Loures-Barousse-Barbazan basin ( $\mathrm{LBBb}$ ) and reaching an elevation of 420-440 m a.s.l. (Andrieu 1991; Calvet et al. 2011). Previous studies based on the degree of soil development and on the state of the weathering of granite cobbles and boulders contained within the glacial sediments revealed the presence of two main morainic complexes in that area: (i) the outermost one surrounding the external northern fringe of the basin is supposed to correspond to the Penultimate Glacial Cycle (PGC; i.e., 192-135 ka; Obrochta et al. 2014), while (ii) the moraine ridges distributed across the internal part of the basin were associated with the LGC (Hubschman 1975, 1984; Stange et al. 2014). Radiocarbon ages obtained within the Barbazan glaciolacustrine sequence confirmed this relative chronology (Andrieu 1991; Andrieu et al. 1988), even if these ages are controversial, as potential problems associated with hard water effect in the carbon content were raised by other authors (Pallàs et al. 2006).

To shed light on the glacial chronology of the largest expansion of the PGC and LGC glaciers in the northern slope of the Pyrenees, new Cosmic-Ray Exposure (CRE) ages are presented from glacial landforms distributed across the $\mathrm{LBBb}$ aiming to answer the following questions:

- When did Pleistocene glaciers reach their maximum extent in the Central Pyrenees?
- Are there glacial remnants from the PGC as previously inferred from post-depositional weathering intensity criteria?

- When did glaciers start retreating and abandoned the Loures-Barousse-Barbazan terminal basin during the LGC?

- Is the timing of glacial oscillations similar to that of the other Pyrenean, Iberian and European mountain ranges?

\section{Study area}

The Pyrenees stretch from the Mediterranean Sea to the Bay of Biscay across $\sim 450 \mathrm{~km}$ long and $100 \mathrm{~km}$ width and divide the Iberian and European tectonic plates. The geographical centre of the range coincides with the highest peaks and a major hydrographic divide, where several rivers drain towards the northern (Aquitaine Basin) and the southern (Ebro Basin) slopes.

The Upper Garonne constitutes one of the largest glacial catchments of the northern Central Pyrenees $\left(1260 \mathrm{~km}^{2}\right.$; Fernandes et al. 2017). It exceeds an elevation of $3000 \mathrm{~m}$ in several peaks (e.g., Perdiguero Peak, 42 41'31 "N-0 31'08", 3219 m; Maupas Peak, 3111 m; Molières Peak, 3009 m; Besiberri Nord Peak, $3007 \mathrm{~m}$ ) and reach 420-440 $\mathrm{m}$ at the frontal position of the PGC and LGC palaeoglaciers. The Ruda Valley, located in the Aran Valley (Fig. 1B), constitutes the headwaters of the Garonne River that receives several other tributaries downvalley to become one of the largest rivers of the Pyrenees; at the Tonneins River gauging station, for example, the Garonne River reports an annual average discharge of $603 \mathrm{~m}^{3} \mathrm{~s}^{-1}$ (1913-2013 series). The abundant discharge results from the Atlantic climate regime, with high precipitation and moderate to cool temperatures. Mean annual air temperature and annual precipitation range from $3{ }^{\circ} \mathrm{C}$ and $1122 \mathrm{~mm}$ at the Bonaigua station $(2266 \mathrm{~m}$; 2000-2020 series) to $12{ }^{\circ} \mathrm{C}$ and $852 \mathrm{~mm}$ at Clarac $(401 \mathrm{~m}$; 2000-2020 series). The precipitation rising and temperature dropping at higher elevations is controlled by the topography of the north face of the range. The elevation difference $(\sim 2800 \mathrm{~m})$ of the catchment determines a wide range of snow regimes: whereas snow remains in the ground over 8-10 months in the highest areas, the LBBb records scarce snow fall (ANR SCAMPEI: http://www.umr-cnrm.fr/scamp ei/presentation_scampei/index.php).

The current landscape of the Pyrenees results from both tectonic dynamics and Pleistocene climatic oscillations that have reshaped the environment through glacial, periglacial, alluvial, fluvial and slope processes (Oliva et al. 2019). The $\mathrm{LBBb}$ is located at the foreland of the Pyrenees and it is flanked in the northern side by the alluvial megafans of the Lannemezan Formation, which were built by the Neste River during the Late Neogene ( $10 \mathrm{Ma}$; Calvet et al. 2021). The 
margins of the basin are surrounded by small hills composed of Jurassic-lower Cretaceous limestones standing 200-300 m above the basin floor, such as Picon Garros Peak (631 m), Castillon Peak (684 m), Mail de Mau Bourg Peak (746 m), and le Picon Peak (777 m) (Fig. 1B). The headwaters of the Garonne Valley are located in the Maladeta batholith, of Carboniferous age (granites and granodiorites), while in the lower areas, there are Cambrian to Devonian sedimentary (conglomerates, limestones, lutites, sandstones) and metamorphic rocks (marbles, slates, schists, quartzites, hornfels; ICGC 2017; Quesada and Oliveira. 2019). Up waters, the Garonne Valley narrows and the river flows through steep river gorges until the Marignac basin (490 m), which is surrounded by peaks up to $1600 \mathrm{~m}$ (e.g., Cap de Pouy de Hourmigué Peak 1609 m). Currently, deciduous forest extends over most of the LBBb, particularly across the surrounding hills and moraine ridges distributed on the basin floor. In the forest-free areas across the bottom of the basin, cultivated fields and dispersed villages occupy the terraces built up by the Garonne River.

\section{Methodology}

The reconstruction of past glacial oscillations in the Upper Garonne Valley integrates geomorphological observations, geochronological data, and palaeoglacier reconstructions. Field work was conducted during the summer seasons of
2019 and 2020 to better identify the main geomorphological features and directly sample glacial landforms for CRE dating.

\section{Geomorphological mapping}

Based on visual interpretation of satellite imagery from Google Earth ${ }^{\circledR}$, ortophotomaps ( $0.5 \mathrm{~cm}$ resolution), 10 -m resolution digital elevation model (DEM) from the 'Institut National de L'information Geographique et Forestière', the recent overviews of past glaciations in the Pyrenees (Delmas et al. 2021a,b) and on the Carte géologique 1:50,000 1054 N, BRGM (https://www.geoportail.gouv.fr/2, a geomorphological map was produced focused on the glacial landforms extending across the area from the LBBb to the Marignac basin. This map was in situ validated and complemented with further field observations.

\section{Sampling strategy related to CRE datings}

After the geomorphological survey, 12 samples were collected from the main units highlighted in the aforementioned map for CRE dating following the standard procedures outlined in Gosse and Phillips (2001). Well-anchored moraine boulders of quartzite, granite and aplite and glacially polished bedrock surfaces (quartzite), were sampled for CRE dating. Sampling was restricted to flat-topped features and gentle surfaces (Table 1). Geometric correction of the

Table 1 Sample and field data

\begin{tabular}{|c|c|c|c|c|c|c|c|}
\hline Sample name & Landform & Latitude (DD) & Longitude (DD) & $\begin{array}{l}\text { Elevation } \\
(\mathrm{m} \text { a.s.1. })^{\mathrm{a}}\end{array}$ & $\begin{array}{l}\text { Topographic } \\
\text { shielding factor }\end{array}$ & Thickness $(\mathrm{cm})$ & Lithology \\
\hline \multicolumn{8}{|c|}{ Outermost moraines (EM) } \\
\hline ARAN-01 (EM-2) & Moraine boulder & 43.0537 & 0.5502 & 477 & 0.9995 & 2.0 & Quartzite \\
\hline ARAN-02 & Moraine boulder & 43.0538 & 0.5497 & 481 & 0.9995 & 2.0 & Quartzite \\
\hline ARAN-44 (EM-4) & Moraine boulder & 43.0388 & 0.5598 & 475 & 0.9871 & 3.0 & Aplite \\
\hline ARAN-45 & Moraine boulder & 43.0389 & 0.5598 & 475 & 0.9994 & 2.8 & Quartzite \\
\hline ARAN-46 & Moraine boulder & 43.0389 & 0.5598 & 474 & 0.9972 & 4.5 & Quartzite \\
\hline \multicolumn{8}{|c|}{ Highest erratic boulder (EM) } \\
\hline ARAN-81 & Erratic boulder & 43.0098 & 0.6036 & 680 & 0.9996 & 3.0 & Granite \\
\hline \multicolumn{8}{|c|}{ Highest moraines of the EM } \\
\hline ARAN-03 & Moraine boulder & 43.0466 & 0.6060 & 674 & 1.0000 & 4.0 & Quartzite \\
\hline ARAN-04 & Moraine boulder & 43.0473 & 0.6078 & 658 & 0.9966 & 4.0 & Quartzite \\
\hline \multicolumn{8}{|l|}{ Internal moraines (IM) } \\
\hline ARAN-05 (IM-1) & Moraine boulder & 43.0425 & 0.6114 & 576 & 0.9989 & 4.0 & Granite \\
\hline ARAN-07 & Moraine boulder & 43.0332 & 0.6301 & 590 & 0.9915 & 5.0 & Granite \\
\hline \multicolumn{8}{|l|}{ Polished surfaces } \\
\hline ARAN-42 & Polished surface & 42.9291 & 0.6454 & 541 & 0.9758 & 4.5 & Quartzite \\
\hline ARAN-43 & Polished surface & 42.9287 & 0.6459 & 525 & 0.9785 & 2.5 & Quartzite \\
\hline
\end{tabular}

a Elevations derived from the $5 \mathrm{~m}$ Digital Elevation Model from the Spanish "Instituto Geográfico Nacional" and the French "l'Institut national de l'information géographique et forestière" are subjected to a vertical accuracy of $\pm 5 \mathrm{~m}$ 
topographic shielding by the surrounding topography was calculated throughout the ArcGIS toolbox based on the digital elevation model of $5 \mathrm{~m}$ resolution, which was devised by Li (2018).

\section{Laboratory procedures and CRE age calculation}

After field work, samples were crushed and sieved to the $125-500 \mu \mathrm{m}$ fraction, and subsequently, $>200 \mathrm{~g}$ of it were chemically processed at the 'Laboratoire National des Nucléides Cosmogéniques' $\left(\mathrm{LN}_{2} \mathrm{C}\right)$ of the 'Centre Européen de Recherche et d'Enseignement des Géosciences de l'Environnement' (CEREGE; Aix-en-Provence, France). According to the quartz-rich lithology, samples were processed for the extraction of the in-situ-produced cosmogenic nuclide ${ }^{10} \mathrm{Be}$.

First, the magnetic minerals of the samples were discarded through magnetic separation conducted in a "Frantz LB-1" magnetic separator. After that, chemical attacks with a concentrated mixture of hydrochloric $(1 / 3 \mathrm{HCl})$ and hexafluorosilicic $\left(2 / 3 \mathrm{H}_{2} \mathrm{SiF}_{6}\right)$ acids and successive partial dissolutions with concentrated hydrofluoric acid (HF). Purified quartz was spiked with $150 \mu \mathrm{L}$ of an in-house manufactured (from a phenakite crystal) ${ }^{9} \mathrm{Be}$ carrier solution $(3025 \pm 9 \mu \mathrm{g}$
${ }^{9} \mathrm{Be}^{-1}$; Merchel et al. 2008), then totally dissolved through a HF leaching, and finally $\mathrm{Be}$ was isolated using ion exchange columns (Merchel and Herpers 1999).

Final $\mathrm{BeO}$ targets were mixed with niobium powder and loaded in copper cathodes. Their ${ }^{10} \mathrm{Be} /{ }^{9} \mathrm{Be}$ ratios were measured in the 'Accelerator pour les Sciences de la Terre, Environnement et Risques' (ASTER) national AMS facility at CEREGE, from which the ${ }^{10} \mathrm{Be}$ concentrations were inferred (Table 2). AMS measurements were calibrated against the in-house standard STD-11 with an assigned ${ }^{10} \mathrm{Be} /{ }^{9} \mathrm{Be}$ ratio of $(1.191 \pm 0.013) \times 10^{-11}$ (Braucher et al. 2015).

${ }^{10} \mathrm{Be}$ exposure ages were calculated using the CREp online calculator (Martin et al. 2017; http://crep.crpg. cnrs-nancy.fr/\#/) with the following settings: LSD (LiftonSato-Dunai) elevation/latitude scaling scheme (Lifton et al. 2014), ERA40 atmospheric model (Uppala et al. 2005) and geomagnetic database based on the LSD framework (Lifton et al. 2014). The 'world mean' production rate derived from the ICE-D online calibration data set (Martin et al. 2017; available online at: http://calibration.ice-d.org/) was chosen, which yielded a sea level high-latitude (SLHL) ${ }^{10} \mathrm{Be}$ production rate of $3.98 \pm 0.22$ atoms $\mathrm{g}^{-1} \mathrm{yr}^{-1}$. Exposure ages and $1 \sigma$ full and analytical uncertainties of the samples are shown in Table 2. The uncertainties discussed throughout

Table 2 Analytical data and calculated ${ }^{10} \mathrm{Be}$ exposure ages

\begin{tabular}{|c|c|c|c|c|c|c|c|c|}
\hline Sample nam & & $\begin{array}{l}\text { Quartz } \\
\text { weight (g) }\end{array}$ & $\begin{array}{l}\text { mass of carrier } \\
\left({ }^{9} \mathrm{Be} \mathrm{mg}\right)\end{array}$ & $\begin{array}{l}\text { ASTER AMS } \\
\text { cathode number }\end{array}$ & ${ }^{10} \mathrm{Be} /{ }^{9} \mathrm{Be}\left(10^{-14}\right)$ & $\begin{array}{l}\text { Blank correction } \\
(\%)\end{array}$ & $\begin{array}{l}{\left[{ }^{10} \mathrm{Be}\right]\left(10^{4} \text { atoms } \mathrm{g}^{-}\right.} \\
\left.{ }_{1}\right)\end{array}$ & Age (ka) \\
\hline \multicolumn{9}{|c|}{ External frontal moraines (EM) } \\
\hline ARAN-01 & \multirow{2}{*}{ EM-2 } & 11.41 & 0.459 & CHAU & $25.54 \pm 0.96$ & 0.77 & $68.17 \pm 2.57$ & $123.8 \pm 7.8(4.5)$ \\
\hline ARAN-02 & & 11.66 & 0.464 & CHAV & $8.96 \pm 0.59$ & 2.20 & $23.32 \pm 1.57$ & $41.6 \pm 3.4(2.6)^{\mathrm{a}}$ \\
\hline ARAN-44 & EM-4 $(n=3)$ & 18.70 & 0.443 & IGNJ & $43.71 \pm 1.46$ & 0.44 & $68.85 \pm 2.30$ & $127.9 \pm 8.0(4.2)$ \\
\hline ARAN-45 & $124.1 \pm 9.6$ & 20.45 & 0.441 & IGNK & $44.37 \pm 2.80$ & 0.43 & $63.63 \pm 4.04$ & $116.4 \pm 9.4(7.1)$ \\
\hline ARAN-46 & $(5.5) \mathrm{ka}$ & 20.76 & 0.440 & IGNL & $48.89 \pm 2.29$ & 0.39 & $68.95 \pm 3.24$ & $128.5 \pm 9.1(6.0)$ \\
\hline \multicolumn{9}{|c|}{ Highest erratic boulder (EM) } \\
\hline ARAN-81 & & 19.23 & 0.438 & IGNU & $5.97 \pm 0.57$ & 3.34 & $8.79 \pm 0.86$ & $13.9 \pm 1.5(1.3)$ \\
\hline \multicolumn{9}{|c|}{ Highest moraines of the EM } \\
\hline ARAN-03 & & 11.19 & 0.455 & CHAW & $17.9 \pm 0.55$ & 1.93 & $47.65 \pm 1.49$ & $73.1 \pm 4.6(2.3)$ \\
\hline ARAN-04 & & 11.61 & 0.454 & CHAX & $7.90 \pm 0.34$ & 4.49 & $19.77 \pm 0.91$ & $31.1 \pm 2.1(1.4)$ \\
\hline \multicolumn{9}{|c|}{ Internal moraines } \\
\hline ARAN-05 & \multirow{2}{*}{ IM-1 } & 10.88 & 0.457 & CHAY & $4.54 \pm 2.62$ & 8.04 & $11.78 \pm 7.35$ & $20.3 \pm 12.7$ \\
\hline ARAN-07 & & 11.44 & 0.460 & CHAZ & $4.01 \pm 0.36$ & 9.10 & $9.89 \pm 0.96$ & $17.1 \pm 1.8(1.6)$ \\
\hline \multicolumn{9}{|c|}{ Polished surfaces } \\
\hline ARAN-42 & & 21.36 & 0.432 & IGNH & $8.58 \pm 0.29$ & 2.33 & $11.34 \pm 0.39$ & $20.7 \pm 1.2(0.7)$ \\
\hline ARAN-43 & & 18.38 & 0.436 & IGNI & $8.67 \pm 0.60$ & 2.29 & $13.42 \pm 0.95$ & $24.2 \pm 2.1(1.6)$ \\
\hline
\end{tabular}

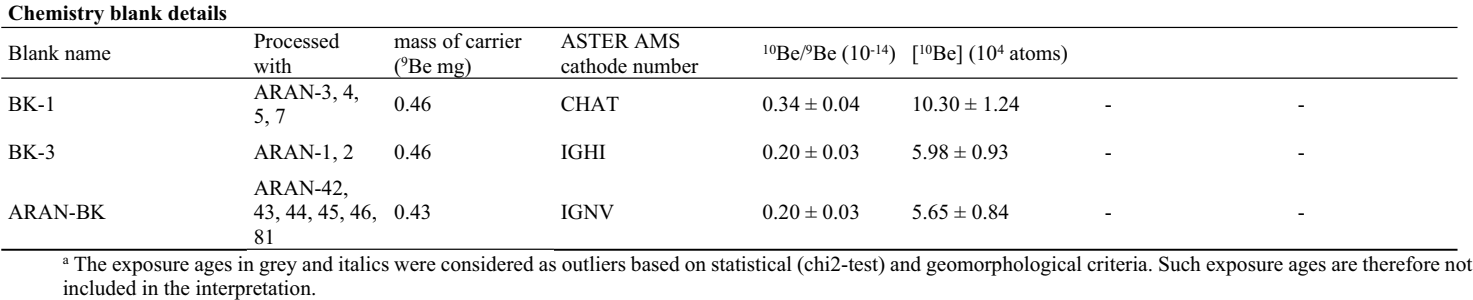

\footnotetext{
${ }^{10} \mathrm{Be} /{ }^{9} \mathrm{Be}$ ratios were inferred from measurements at the ASTER AMS facility. Individual ages are shown with their full uncertainties (including analytical AMS uncertainty and production rate uncertainty) and analytical uncertainty only within brackets. Arithmetic mean ages are given with their full uncertainties (including standard deviation and production rate uncertainty) and standard deviations only in brackets
} 
the text include analytical and production rate error unless otherwise stated.

To evaluate the potential impact of the erosion on the exposure ages, the same corrections outlined in Oliva et al. (2021) was implemented, which resulted in older ages by $\sim 1 \%$ and $~ 8 \%$ for the 0.2 and $1 \mathrm{~mm} \mathrm{ka}^{-1}$ scenarios (André 2002), respectively. However, aiming to enable comparisons with other areas the non-corrected ages was retained along the text. Snow cover is at present close to zero in the $\mathrm{LBBb}$ and is thus considered negligible. The high external and internal errors of the samples ARAN-05 and ARAN-81, linked to low current values during the AMS measurement implies that such samples and their derived exposure ages must be rejected. The chi-squared test was applied using the iceTEA tool (http://ice-tea.org/en/tools/remove-outliers/; Jones et al. 2019) to detect potential outliers within the targeted geomorphic units; thus, the exposure age of the sample ARAN-02 was excluded due to the statistical inconsistence.

\section{Palaeoglaciers and palaeoELAs reconstruction}

A three-dimensional palaeoglacier reconstruction was carried out for the different glacial phases using the 'GLaRe' ArcGIS toolbox developed by Pellitero et al. (2016) and a 10-m resolution DEM, which implements a perfect-plasticity physical-based numerical model (Van der Veen 1999; Benn and Hulton 2010) that reconstructs past ice thickness assuming an average shear stress of $100 \mathrm{kPa}$ along a set of flowlines (Paterson 1994; Benn and Hulton 2010). And finally, equilibrium-line altitudes (ELAs) were calculated using the automatic toolbox developed by Pellitero et al. (2015) through the methods Accumulation Area Ratio (Porter 1975; AARs: $0.6 \pm 0.05$ ) and the Area Altitude Balance Ratio (AABR; Osmaston 2005). For more details on glacier reconstruction and ELA calculation protocols, the reader is referred to Oliva et al. (2021) and the original publications from which the aforementioned toolboxes were derived.

\section{Results}

The distribution of the glacial landforms preserved in the $\mathrm{LBBb}$ evidence several glacial advances and retreats during the Pleistocene (Fig. 2). Their timing is constrained by the ${ }^{10} \mathrm{Be}$ exposure ages obtained from moraine boulders and polished surfaces (Tables 2, 3).

\section{Glacial geomorphological setting}

Glacial deposits located in the LBBb have been largely transformed by historical human practices (e.g., agriculture) and by a dense network of infrastructures that have affected the natural landscapes and the preservation of glacial landforms.
In addition, the entire area-particularly the slopes-is extensively forested, which makes even more challenging the interpretation of glacial features as well as the identification of appropriate samples for CRE dating (Figs. 3, 4).

Nonetheless, based on our field work observations and on previous geomorphological mapping (Carte géologique 1:50,000 1054 N, BRGM; Delmas et al. 2021a), two main glacial systems were identified (Fig. 3):

\section{The external moraine system (EM)}

There are only well-preserved deposits in the terminal zone of the palaeoglacier, downstream the villages of Izaourt and Tibiran-Jaunac. It consists of the highest moraines of the EM in the internal and eastern parts of the basin and four moraine ridges in the western side of the basin floor (Fig. 4). The highest moraines of the EM are distributed on the slopes and hilltops of the internal part of the basin (Fig. 2b). At elevations between 600 and $720 \mathrm{~m}$ (i.e., $160-280 \mathrm{~m}$ above the basin floor) there are exposed sections opened on this moraine showing subangular to subrounded meter-sized granite and quartzite boulders embedded in a poorly sorted matrix. At the same altitude but close to Izaourt, several erratic granite boulders rest on a limestone bedrock that may correspond to the same phase (Fig. 3).

Further north, at lower altitudes (600-670 m), the highest moraines of the EM on the hilltop surface of the Castillon Peak do not define well-preserved moraine ridges, but patches of till deposits are located towards the eastern edge of the basin. Here, there are also sparse boulders and glaciofluvial sediments embedded in a sandy matrix. At the western side of the basin floor, moraines form aligned discontinuous ridges at 460-490 m (i.e., up to 40-70 m height), with well-developed soils and sparse boulders across the surface. These features are extensively forested. Up to four moraine ridges were identified in this system (Figs. 3, 4A):

EM-1-located at the northernmost part of the basin floor and represents the most peripheral moraine ridge preserved in the study area;

EM-2-stretching between the Tibiran and Jaunac villages, this ridge displays an oblique feature with regards to the palaeo ice-flow;

EM-3-located $500 \mathrm{~m}$ to the south from the outer ridge, and turns from SW-NE to S-N towards Jaunac village;

EM-4-located $300 \mathrm{~m}$ north from the St-Martin village.

To validate the connection between the highest moraines close to the Castillon Peak and the external ridges near Tibiran-Jaunac villages, the area was extensively surveyed to identify potential boulders suitable for CRE dating. Hubschman (1984) attributed those frontal moraines to glacial advances prior to the Eemian Interglacial. To test this 

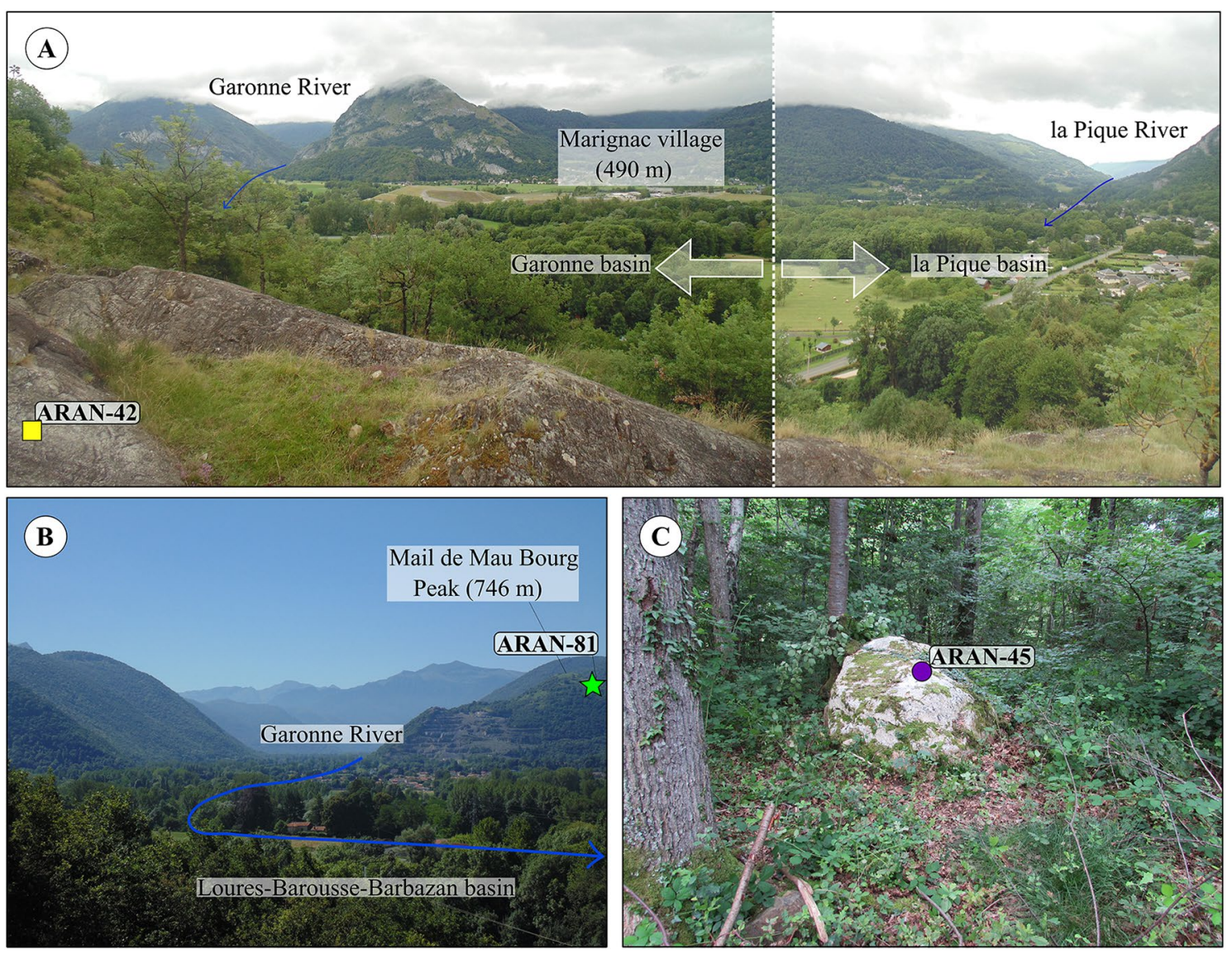

Fig. 2 Examples of the samples collected from the polished surface in the Marignac basin (A; ARAN-42), and the erratic boulder (B; ARAN81) and moraine boulder (C; ARAN-45) from the Loures-Barousse-Barbazan basin

Table 3 Exposure ages according to different erosion scenario corrections

\begin{tabular}{|c|c|c|c|c|}
\hline \multirow[t]{2}{*}{ Sample name } & & \multicolumn{3}{|c|}{ Exposure ages (arithmetic mean, in ka) } \\
\hline & & No correction & $\begin{array}{l}\text { Erosion correction }(0.2 \\
\mathrm{mm} / \mathrm{ka})\end{array}$ & $\begin{array}{l}\text { Erosion correction (1 } \\
\mathrm{mm} / \mathrm{ka})\end{array}$ \\
\hline \multicolumn{5}{|c|}{ Outermost moraines (EM) } \\
\hline ARAN-1 & & $123.8 \pm 7.8(4.5)$ & $127.1 \pm 8.2(4.7)$ & $143.4 \pm 9.7(5.6)$ \\
\hline ARAN-2 & EM-2 & $41.6 \pm 3.4(2.6)$ & $42.0 \pm 3.4(2.7)$ & $43.4 \pm 3.6(2.8)$ \\
\hline ARAN-44 & & $127.9 \pm 8.0(4.2)$ & $131.4 \pm 8.3(4.4)$ & $149.3 \pm 9.7(5.1)$ \\
\hline ARAN-45 & EM-4 & $116.4 \pm 9.4(7.1)$ & $119.3 \pm 9.6(7.3)$ & $133.0 \pm 11.1(8.5)$ \\
\hline ARAN-46 & & $128.5 \pm 9.1(6.0)$ & $132.0 \pm 9.4(6.2)$ & $150.1 \pm 11.0(7.2)$ \\
\hline mean & & $124.1 \pm 9.6(5.5)$ & $127.8 \pm 11.7(6.0)$ & $144.1 \pm 14.4(6.9)$ \\
\hline \multicolumn{5}{|c|}{ Highest moraines } \\
\hline ARAN-3 & & $73.1 \pm 4.6(2.3)$ & $74.3 \pm 4.7(2.3)$ & $79.3 \pm 5.0(2.5)$ \\
\hline ARAN-4 & & $31.1 \pm 2.1(1.4)$ & $31.2 \pm 2.1(1.4)$ & $32.0 \pm 2.1(1.4)$ \\
\hline \multicolumn{5}{|c|}{ Highest erratic boulder } \\
\hline ARAN-81 & & $13.9 \pm 1.5(1.3)$ & $14.0 \pm 1.5(1.3)$ & $14.1 \pm 1.5(1.3)$ \\
\hline \multicolumn{5}{|c|}{ Innermost moraines (IM) } \\
\hline ARAN-7 & $(\mathrm{IM}-1)$ & $17.1 \pm 1.8(1.6)$ & $17.2 \pm 1.8(1.6)$ & $17.4 \pm 1.9(1.6)$ \\
\hline \multicolumn{5}{|c|}{ Polished surfaces } \\
\hline ARAN-42 & & $20.7 \pm 1.2(0.7)$ & $20.8 \pm 1.2(0.7)$ & $21.1 \pm 1.3(0.7)$ \\
\hline ARAN-43 & & $24.2 \pm 2.1(1.6)$ & $24.3 \pm 2.1(1.6)$ & $24.8 \pm 2.1(1.7)$ \\
\hline
\end{tabular}

a The exposure ages in grey and italics were considered as outliers based on statistical (chi2-test) and geomorphological criteria. Such exposure ages are therefore discarded across the text. 
Fig. 3 Geomorphological map of the study area modified from Delmas et al. (2021a,b)

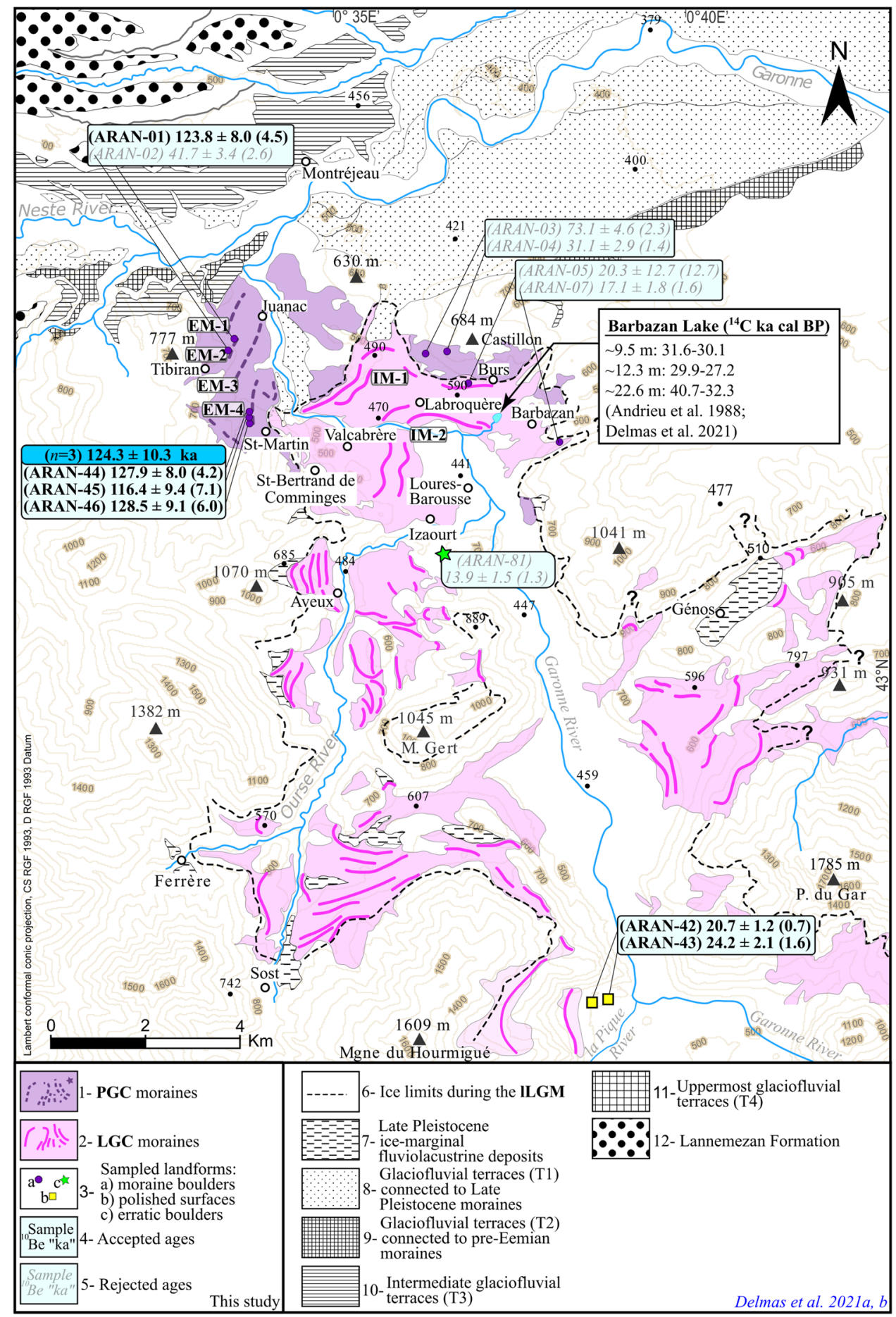

hypothesis, seven samples were collected from scattered moraine boulders belonging to the following units: the highest moraines of the EM (ARAN-03, ARAN-04), EM-2 (ARAN-01, ARAN-02) and EM-4 (ARAN-44, ARAN-45, ARAN-46). The few boulders found on EM-1 and EM-3 moraine ridges were not adequate for CRE dating as they had seemingly been disturbed from their original position, and therefore, no samples were collected.

\section{The internal moraine system (IM)}

A series of moraine ridges are distributed across the internal part of the LBBb floor at $460-590 \mathrm{~m}$ and the valley sides of the glacial catchment, at 550-820 m (Fig. 3), forming discontinuous ridges in the margins of the palaeoglacier. This well-preserved moraine system is composed of two sets of arches that are distributed on the LBBb and connects with 


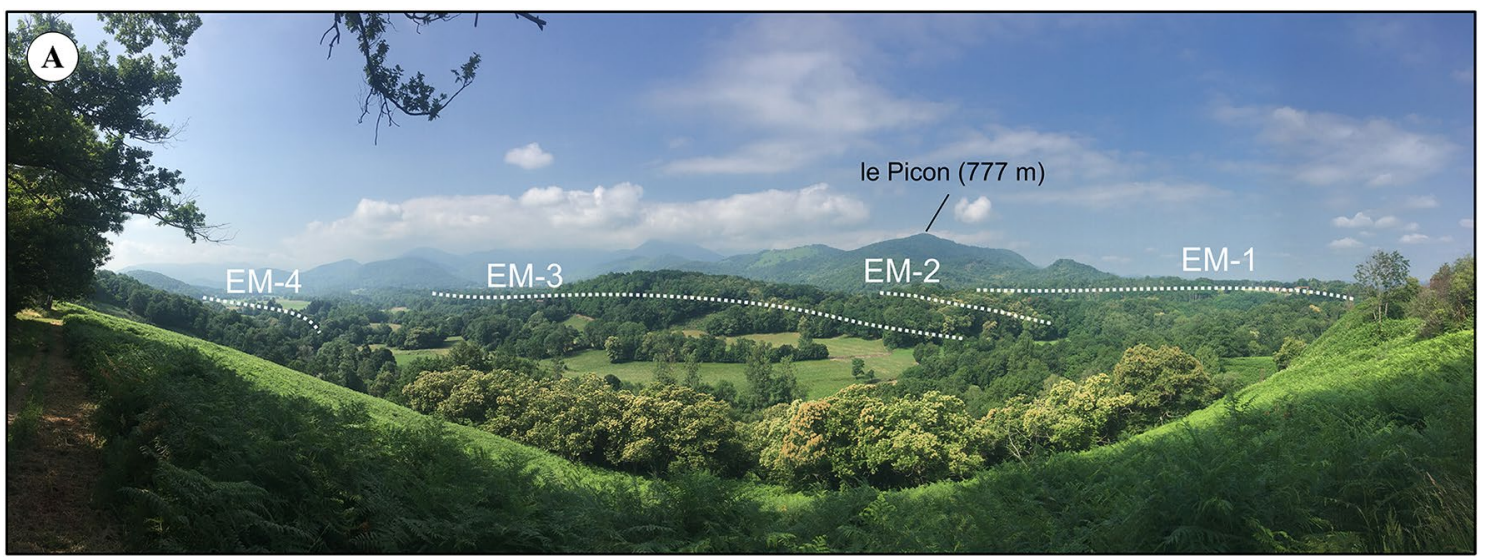

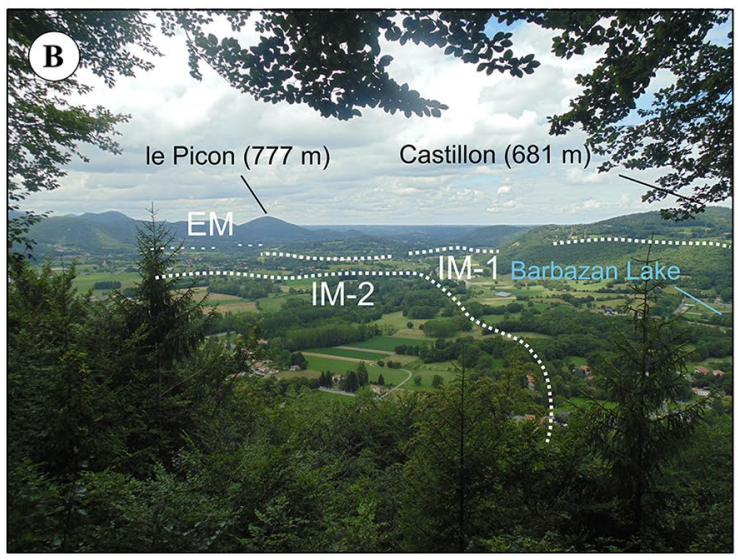

Fig. 4 Moraine complex in the Loures-Barousse-Barbazan basin: A Panoramic view of the northernmost part of the basin and moraine ridges of the external moraine system; $\mathbf{B}$ moraine ridge IM-1 seen

lateral moraine ridges. Those moraine ridges are indicative of the frontal termination of the Garonne palaeoglacier in the $\mathrm{LBBb}$ and of the lateral margins, where glacial deposits (ablation moraines and fluviolacustrine obturations) delineate large glacial diffluences that the Garonne palaeoglacier spread across the structural hills framed by the Jurassic-lower Cretaceous limestones of the North Pyrenean zone. Sedimentological, palynological and radiocarbon data obtained in the Barbazan glaciolacustrine sequence allow two main units to be distinguished within the LGC moraine system of the Garonne palaeoglacier (Fig. 3). Thus, two units were considered in the internal moraine system (Fig. 3):

IM-1-In the terminal zone of the LBBb, IM-1 corresponds to a $5 \mathrm{~km}$-long moraine preserved between Burs and St-Martin. Metric-size and well-anchored granite boulders were found in the Eastern margin of the moraine, lying on the foot slopes of Barbazan. Near Burs, the ridge rapidly decreases in elevation (from 590 to $490 \mathrm{~m}$ ) towards the central part of the basin, connecting with a 30-m-high arcuate frontal ridge at La Serre.

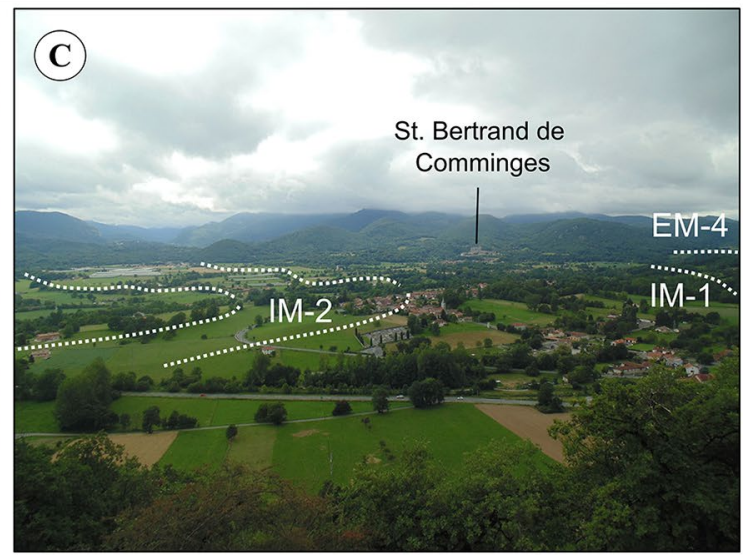

from the southernmost part of the basin; $\mathbf{C}$ moraine ridges IM-2 viewing from the Burs village

In this section, and especially on the slope between Burs and the Barbazan paleolake, several sedimentary sequences contain meter-sized subrounded to rounded boulders of granite and quartzite, embedded in a sand and silt matrix. From the La Serre arch, the ridge turns westwards and ends $500 \mathrm{~m}$ next to the EM-4 ridge. In this section, several scattered boulders were detected at the north margin of the river and in south part of the St-Marti village. Only two samples were collected from the IM-1 ridge near Burs and Barbazan villages (ARAN-05, ARAN-07), at similar altitudes of 580 and $590 \mathrm{~m}$ (Table 1). On the lateral left moraine system, 2 $\mathrm{km}$ upvalley from the $\mathrm{LBBb}$, there are lateral ridges close to Aveux and Sacoué villages that are indicative of the palaeoglacier margins at the glacial diffluence. Further south, $6 \mathrm{~km}$ upvalley from the LBBb, frontal and lateral moraines lying between 620 and $800 \mathrm{~m}$ at the Sost-Ferrère glacial villages are also part of this moraine system. Finally, at the right moraine complex of the palaeoglacier margin, there are several lateral and frontal ridges distributed between 610 and 780 m near Lourde-St-Pé-d'Ardet-Génos villages; 
IM-2-In the innermost part of the terminal zone of the LBBl, the IM- 2 consists on two parallel moraine ridges (10 $\mathrm{m}$ high) located close to the current basin floor between Valcabrère, Labroquère and Loures-Barousse villages. Further south, in the moraine system of SostFerrère, the most internal ridges standing at 580-600 $\mathrm{m}$ might correspond to the palaeoglacier margins of the IM-2. In the opposite side, this phase can be represented by lateral and frontal ridges at 530-610 $\mathrm{m}$ at the LourdeSt-Pé-d'Ardet-Génos. Despite these lobate ridges surrounding the basin define well-preserved features, they have been intensely disturbed by agriculture activities. Therefore, no suitable boulders for CRE dating were found in the area as they were probably not in the original place, where the ice left them.

Up-valley from the $\mathrm{LBBb}$, the main valley narrows and no glacial features prone for CRE dating were found until the Marignac basin, $13 \mathrm{~km}$ upvalley, where the Garonne and la Pique rivers converge (Fig. 2). Hubschman (1984) attributed the IM-1 and IM-2 to glacial advances occurred during the LGC. At the left margin of the main Garonne Valley, there are polished surfaces on granite bedrock, at $18 \mathrm{~km}$ from the EM-1 ridge. To validate Hubschman's interpretation, two samples were collected from these surfaces 50 and $30 \mathrm{~m}$ above the riverbed (ARAN-42, ARAN-43), as representative of the age of the withdrawal of the palaeoglacier from the terminal basin, of the lateral moraine complexes and of the individualization of the Garonne and la Pique palaeoglaciers within their respective valleys.

\section{CRE results}

The 10 CRE samples collected from the LBBb yielded ages spanning from $128.5 \pm 9.1$ to $13.9 \pm 1.5 \mathrm{ka}$ (Table 2 ).

From the four moraine ridges integrating the EM moraine system, two samples were obtained from EM-2 (ARAN01, ARAN-02) with inconsistent ages of 123.8 \pm 8.0 and $41.7 \pm 3.4 \mathrm{ka}$, respectively (Table 2 ). At the EM-4 ridge, three samples (ARAN-44, ARAN-45, ARAN-46) yielded consistent ages of $127.9 \pm 8.0,116.4 \pm 9.4$ and $128.5 \pm 9.1 \mathrm{ka}$ (mean age $124.3 \pm 10.3 \mathrm{ka} ; n=3$ ) (Figs. 3, 5).

At the southern part of the LBBb, an erratic boulder located $240 \mathrm{~m}$ above the basin floor (ARAN-81) yielded an age of $13.9 \pm 1.5 \mathrm{ka}$. Due to the bad AMS measurement this age will not be further discussed. The highest moraine of the EM loses altitude northwards, and at 230 and $220 \mathrm{~m}$ above the basin floor two other samples were collected (ARAN-03 and ARAN-04) within a forest area near the Castillon Peak, yielding again inconsistent exposure ages of $73.1 \pm 4.6$ and $31.1 \pm 2.9 \mathrm{ka}$, respectively (Fig. 3).

One sample collected from the IM-1 ridge, close to the Burs village (ARAN-05), reported an exposure age of $20.3 \pm 12.7 \mathrm{ka}$. This age will not be further discussed. At the foot of the slopes surrounding the basin, another sample (ARAN-07) was obtained near the Barbazan village and yielded an age of $17.1 \pm 1.8 \mathrm{ka}$.

The exposure ages of two samples (ARAN-42, ARAN43) obtained from polished surfaces in the overdeepened basin surrounding the Marignac village, are $20.7 \pm 1.2$ and $24.2 \pm 2.1 \mathrm{ka}$, respectively.
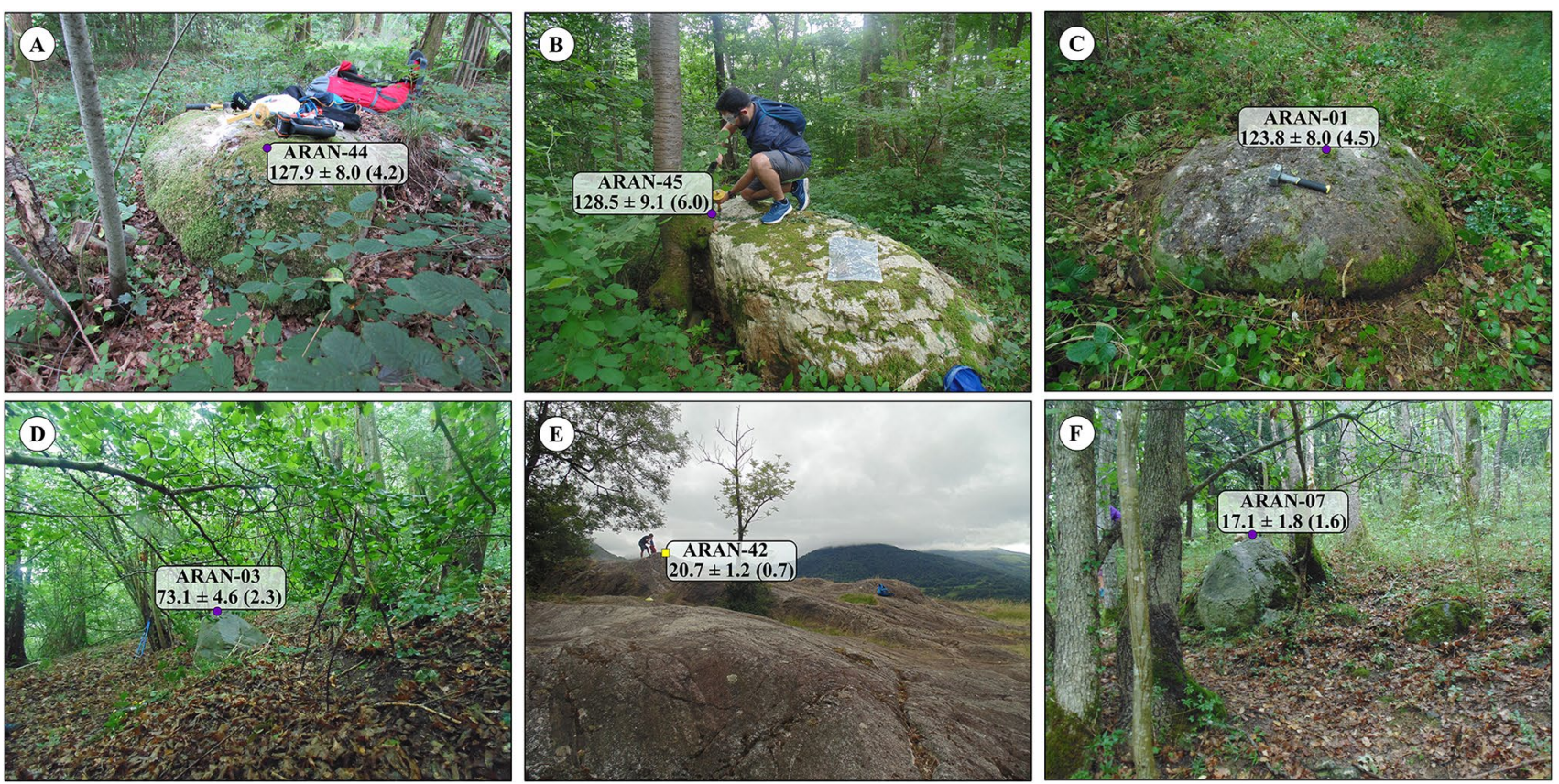

Fig. 5 CRE ages of the different moraine systems from the terminal basin of the Loures-Barousse-Barbazan and polished surfaces upvalley 


\section{Discussion}

The reconstruction of the glacial evolution in the $\mathrm{LBBb}$ is based on geomorphological surveying and mapping, and

${ }^{10} \mathrm{Be}$ exposure ages obtained from moraine boulders and polished surfaces. Data confirms Hubschman's proposal that the most weathered moraine (EM) was formed during a glacial advance prior the Eemian Interglacial, as well as the onset of the final retreat of the Garonne Glacier during the gLGM.

\section{Interpretation of the CRE results}

The sequence of CRE ages from the terminal moraine system of the Upper Garonne Valley is constrained by the long time since the penultimate deglaciation of the area and subsequent postglacial environmental dynamics, which together with land use changes caused by humans within the last millennia in the LBBb, have affected the preservation of the glacial records. Therefore, the reconstruction of the glacial history in the area is challenging, and our study needs to be complemented with other environmental proxies and glacial chronological data from the region.

The exposure ages of the samples (ARAN-01, ARAN44, ARAN-45 and ARAN-46) from boulders distributed on the moraine ridges EM-2 and EM-4 (123.8 $\pm 8.0 \mathrm{ka}$ and $124.3 \pm 10.3 \mathrm{ka}$, respectively) show statistical consistence based on the Chi-2 test. They support the hypothesis that the oldest moraine system existing in the glacial terminal basin of the Upper Garonne Valley corresponds to the PGC. These dates confirm the deposit of those moraines during a glacial advance before the Eemian Interglacial period, as postulated in previous studies (Hubschman 1984; Andrieu et al. 1988).

The exposure ages from the samples taken from the highest moraines of the EM (ARAN-03 and ARAN-04) yielded $73.1 \pm 4.6$ and $31.1 \pm 2.9 \mathrm{ka}$, respectively, showing a lack of consistency between them. These two ages suggest that these moraines might correspond to polygenic features that formed over a long time period when the glacier occupied the top of the Castillon Peak and finally shrunk by $31.1 \pm 2.9$ ka before the onset of the Barbazan Lake infill, located $1.5 \mathrm{~km}$ south (Fig. 4B; Andrieu et al. 1988). However, it is also likely that our boulders had shifted from their original position by subsequent glacial advances or had been exhumated by postglacial erosion processes occurring on the slopes of the Castillon Peak. Therefore, more data is needed to confirm one of the scenarios and verify the link with the maximum glacial advance. Thus, given this uncertainty, for the reconstruction of the glacial history in the area, these samples were excluded.

The exposure age of $17.1 \pm 1.8 \mathrm{ka}$ (ARAN-07) obtained from the IM-1 moraine ridge near Burs must be excluded due to its mismatch with the Barbazan Lake records located upvalley, which indicates an older retreat than our exposure ages (Andrieu et al. 1988):

(i) A radiocarbon age of $31.160 \pm 1.700 \mathrm{yr} \mathrm{BP}(40.7-$ $32.3 \mathrm{cal} \mathrm{ka} \mathrm{BP})$ at $2263-2274 \mathrm{~cm}$ (base of the core) within the basal unit (glaciolacustrine rhythmites and diamictons). Given the location of the Barbazan paleolake with respect to the IM-1, the area of the lake was covered by the ice when IM-1 was formed. Hence, this proglacial lake may only have infilled after the Garonne Glacier retreated from the IM-1. Hence, IM-1 should be older than 40.7-32.3 cal ka BP.

(ii) The sedimentary frame of the glaciolacustrine sequence shows that the Garonne ice margin was close to the paleolake (probably at IM-2) until the interruption of glacial meltwater supply. This interruption occurred at $26.600 \pm 460 \mathrm{yr}$ BP (31.6-30.1 cal ka BP; Andrieu 1991), or just after $23.980 \pm 680 \mathrm{yr}$ BP (29.9-27.2 cal ka BP). It is, however, possible that the moraine boulders from the IM-1 ridge have been affected by reworking following 1 LGM glacial retreat and provide thus younger ages than expected.

New CRE ages from polished surfaces on the left margin of the Marignac basin (ARAN-42: $20.7 \pm 1.2 \mathrm{ka}$ and ARAN43: $24.2 \pm 2.1 \mathrm{ka}$ ) allow us to locate the terminal position of the Garonne palaeoglacier upstream of Marignac at the time of the gLGM.

\section{Chronology of the glacial advances in the Upper Garonne Valley}

Several smooth moraine ridges were mapped within the external moraine system of the LBBb, and ascribed to the oldest glacial advance in the area (Hubschman 1984; Andrieu 1991; Stange et al. 2014; Fernandes et al. 2017). Our CRE dates reveal two moraine ridges deposited prior to the LGC in the Upper Garonne Valley at $123.8 \pm 8.0$ and $124 \pm 9.6 \mathrm{ka}$. Thus, four CRE dates from the EM-2 and EM-4 ridges provided evidence of moraine stabilization during a time interval spanning from $128.5 \pm 9.1$ to $116.4 \pm 9.4 \mathrm{ka}$ (Table 2). Isotopic inheritance is likely to be absent for moraines far from the source $(\sim 20-80 \mathrm{~km})$; however, the youngest ages might have been exhumated following the onset of moraine stabilization (Briner et al. 2005). Therefore, the oldest age of these units most likely marks the time of moraine stabilization following the MIS 6 largest glacial advance at $\sim 129 \mathrm{ka}$. As temperatures increased during the transition toward the Eemian Interglacial (Helmens 2013), the Garonne Glacier started receding and moraines 
stabilized. This PGC glacial advance must have covered the entire glacial terminal basin of the Upper Garonne Valley with an ice thickness ranging between 200 to $50 \mathrm{~m}$ (Fig. 6). According to our results, during this phase, the main Upper Garonne Glacier was $\sim 78 \mathrm{~km}$ long and covered $\sim 900 \mathrm{~km}^{2}$. Considering the position of the frontal moraine ridge EM-2 at $480 \mathrm{~m}$, and the derived palaeoglacier reconstruction, the ELA was located at $1711 \pm-65 / 55 \mathrm{~m}$ (AAR), $1719 \pm-95 / 60 \mathrm{~m}$ (global AABR) and 1704 $\pm-105 / 70 \mathrm{~m}$ (mid-latitude AABR), with an average of $1711 \mathrm{~m}$. This altitude suggests a reduction of $9.3^{\circ} \mathrm{C}$ with respect of current ELA at $3139 \mathrm{~m}$ and assuming no change in the summer precipitation (Campos et al. 2021). As expected, these results show that glaciers had similar extents in the terminal basin during the MIS 6 and ILGM glacial advances and thus climate conditions were probably similar (Fernandes et al. 2017).

No solid chronological data are available to support a straightforward interpretation of the glacial advance during the PGC. The lack of available boulders for CRE dating in the EM-1 ridge impeded establishing the timing of the maximum extent during the PGC in the Upper Garonne Valley, whose external position on the moraine suggest that it may also belong to the PGC (Fig. 6). Indeed, there is evidence indicating that the Pyrenees were extensively glaciated during this period. In the Eastern Pyrenees, a stalagmitic flowstone stemmed from the onset of karst activity by $124.6 \pm 6.9$ to $121.4 \pm 9.4 \mathrm{ka}$ at the Niaux-Lombrives-Sabart cave occurred after the MIS 6 cold period (Sorriaux et al. 2016). In the same catchment, other age obtained from an erratic boulder located 50-100 $\mathrm{m}$ above the LGC moraines, reinforced the hypothesis of a previous glaciation that took place in the Ariège Valley at $133.9 \pm 5.3 \mathrm{ka}$ (Delmas et al. 2011). In the southern slope of the Pyrenees, an older age from the PGC has also been reported in the Aragón Valley, where the outermost moraine, $80 \mathrm{~m}$ above the present-day riverbed, was dated at $171.0 \pm 22.0 \mathrm{ka}$ (García-Ruiz et al. 2013).

Geomorphological evidence from the LGC in the LBBb must thus be located in the internal part of the basin and foot slopes close to the Barbazan village. Here, the La Serre and the Burs ridges (IM-1) were generated by a piedmont glacier covering the basin during the ILGM of the LGC. The only available ages correspond to the Barbazan Lake sequence, where the onset of the proglacial lake infill, behind this moraine, started before 40.7-32.3 cal ka BP (Hubschman 1984; Andrieu 1991). In several valleys of the southern slope of the Pyrenees, glacial evidence suggests that the ILGM occurred during the MIS 4 and MIS 3, namely, at 65-55 ka and 45-30 ka (Oliva et al. 2019). However, the chronology
Fig. 6 Terminal position of the Garonne palaeoglacier during the glacial advance of the MIS 6

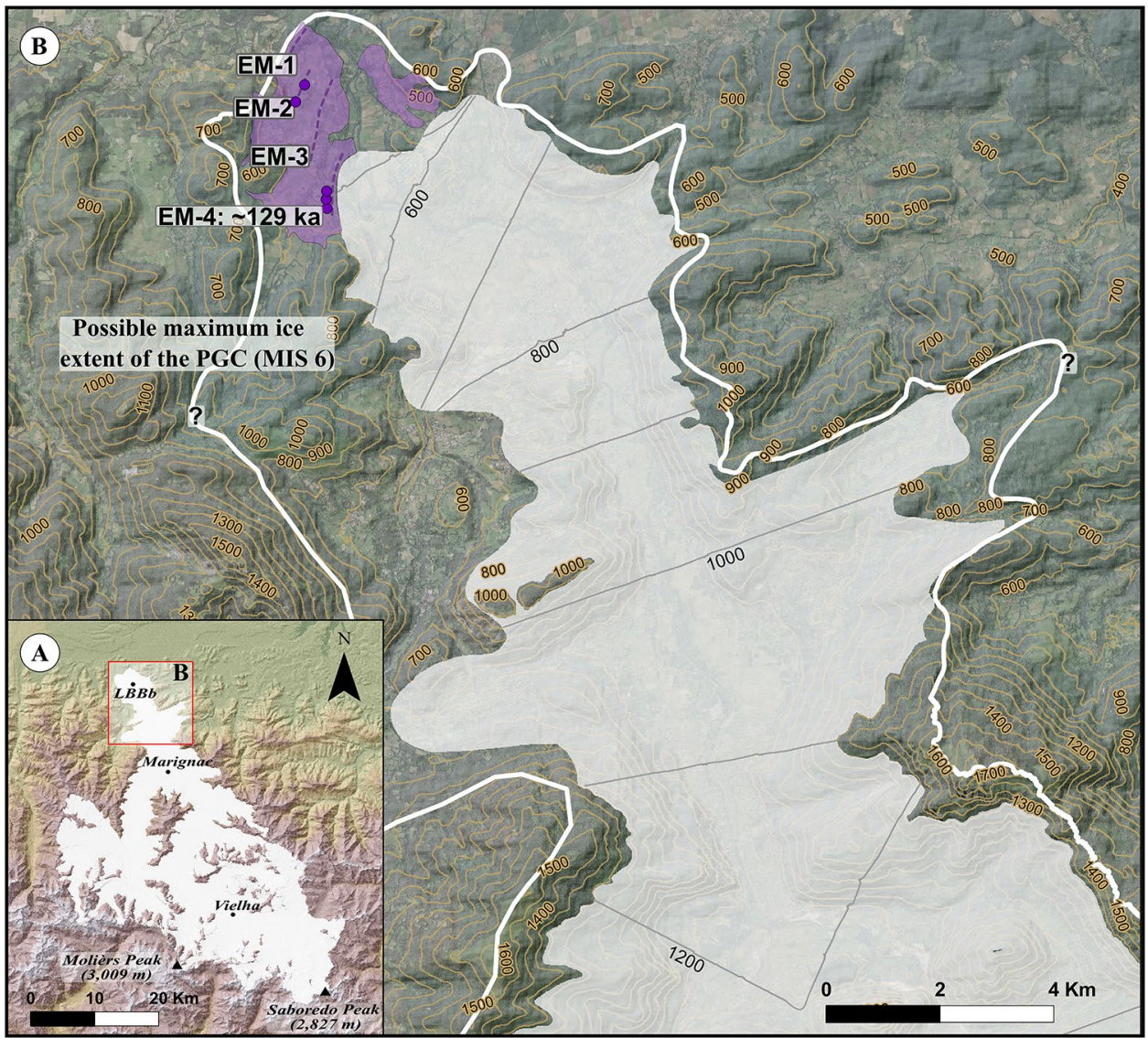


of the ILGM glacial advances in the southern slope is not as robust as in the northern slope. In the Ariège Valley, a CRE age from an erratic boulder located on the hilltop between Tarascon and Foix-Montgaillard basins yielded $79.9 \pm 14.3 \mathrm{ka}$ and a boulder from a lateral moraine on the confluence between the Aston and Ariège valleys yielded an exposure age of $35.3 \pm 8.6 \mathrm{ka}$ (Delmas et al. 2011). In addition, radiocarbon dating of the first organic remnants from the bottom of the ice-marginal deposits behind such moraines has shown the onset of the post-ILGM deglaciation between 48 and $24 \mathrm{ka}$, namely, at the Estarrès Lake, Gave d'Ossau (34.2-29.7 cal ka BP; Andrieu 1987; Andrieu et al. 1988; Jalut et al. 1988), at the Biscaye peatbog, Gave de Pau (48.3-39.7 cal ka BP; Mardones and Jalut 1983), and at the Freychinède sequence, Ariège Valley (27.3-24.0 cal ka BP; Jalut et al. 1982; Reille and Andrieu 1995). Therefore, the ILGM glacial advance of the LGC in the LBBb is necessarily older than the onset of the sedimentation at the Barbazan Lake, as the glaciolacustrine rhythmites and diamictons at the base of the core sequence accumulated after the glacial retreat that followed the previous glacial advance, which likely coincided with the formation of the IM-1 moraine. Glacial advances during the MIS 3 are more evident in the Eastern Pyrenees, where moraines from Têt Valley were dated at $40.86 \pm 1.9 \mathrm{ka}$ (Tomkins et al. 2018) or those in the Malniu area that yielded 51.1 $\pm 4.8-42.6 \pm 4.1$ ka (Pallàs et al. 2010).

After the ILGM recession, a moraine-dammed lake formed between the IM-1 ridge and the glacier front blocked the meltwater discharges and filled the Barbazan proglacial lake (Andrieu 1991). The same author indicated that the glaciolacustrine rhythmites and diamictons at the bottom of the sequence (40.7-32.3 cal ka BP) was transported from a nearby source, probably synchronously with the formation of the moraine IM-2. However, no chronological data are yet available to discriminate whether the moraine was formed during a pulsation after the ILGM or as a result of the gLGM advance. It can only be hypothesized that the ages must be older than 31.6-30.1 cal ka BP, because sediments and pollen records showed the progressive glacial abandonment of the terminal basin, with a transition from glaciolacustrine to lacustrine sediments, a reduction of freshwater inputs from the glacier, as well as the decline of the forest coverage (e.g., Fagus sp.) and the recovery of herbaceous species (Andrieu et al. 1988; Jalut et al. 1992).

The slopes surrounding the Marignac basin were ice-free during the gLGM, as demonstrated by the exposure ages obtained from polished surfaces at 50 and $30 \mathrm{~m}$ above the basin floor. At 24-21 ka, the glacier would have abandoned the terminal basin and split into two individualized glacier tongues constrained within the Garonne and la Pique valleys as the ice shrank. At this time, the palaeoglacier of the Upper Garonne Valley flowed down $60 \mathrm{~km}$ along the main valley. In parallel, glacial recession was also underway during the gLGM in the Ariège Valley, where polished surfaces were dated to $18.7 \pm 3.8 \mathrm{ka}$ at $20 \mathrm{~m}$ above the gLGM Bompas moraine (490 m) (Delmas et al. 2011). In this case the gLGM was depicted with glacial advances leaving several well-preserved moraines (Garrabet, Bernière, Bompas-Arignac): a boulder from the Bernière frontal moraine, $\sim 7 \mathrm{~km}$ from the ILGM ice limits was dated at $18.8 \pm 1.3 \mathrm{ka}$ (Delmas et al. 2011). Subsequently, after the gLGM, glaciers in the Upper Garonne Valley underwent a massive retreat upvalley, reaching the mouth of the highest cirques by $\sim 15-14 \mathrm{ka}$ (Oliva et al. 2021; Fernandes et al. 2021).

\section{Mid-Late Pleistocene glacial dynamics in the Central Pyrenees in the context of European mid-latitude regions}

In Eurasia, climatic models have shown that the glacial maximum of the PGC was the most extensive of the last $400 \mathrm{ka}$ (Colleoni et al. 2016). This glacial maximum occurred at $140 \mathrm{ka}$ (MIS 6) based on Antarctic ice core records (Winograd et al. 1992; Colleoni et al. 2016), which is also confirmed by the minimum sea level (likely $-150 \mathrm{~m}$ ) dated at 155-140 ka (Grant et al. 2014; Wekerle et al. 2016). The Greenland ice core recorded the Eemian Interglacial from 129 to $114 \mathrm{ka}$ with a warming peak occurring at $126 \mathrm{ka}$ (Dahl-Jensen et al. 2013). These records correspond to a sea-level stabilization at 130-119 ka, reaching up to 6-9 m above the current level (Hearty et al. 2007). According to the Greenland ice cores, this interglacial was up to $8 \pm 4{ }^{\circ} \mathrm{C}$ warmer than the last millennium (Dahl-Jensen et al. 2013). The beginning of the Eemian caused a massive ice discharge from Northern Hemisphere ice sheets, when glaciers flowed into the ocean leaving icebergs that drifted debris $\left(>150 \mu \mathrm{m}\right.$ ) southwards as far as $\sim 55^{\circ} \mathrm{N}$ at $128 \mathrm{ka}$ (McManus et al. 1999; Fig. 7). In fact, disintegration of the northern ice sheets occurred during the end of the PGC, which coincided with the Heinrich Stadial 11 ( 136-129; Menviel et al. 2019).

According to marine sediments from the Iberian margins, a rapid warming with an increase of annual sea surface temperatures of $\sim 10{ }^{\circ} \mathrm{C}$ followed the MIS 6 (Martrat et al. 2007). The comparison between the deep-sea cores in the Portuguese margins and European pollen records showed that in southwestern Iberia the warmest and driest period of this interglacial occurred between 126 and $117 \mathrm{ka}$ (SánchezGoñi et al. 2005). Such warm conditions after the MIS 6 suggests non-favourable conditions to glacial development in the Iberian Peninsula. Consequently, it is likely that midlatitude mountain glaciers, such as those existing in the Pyrenees, underwent a massive retreat leaving their terminal basins and probably the lowest peaks. 


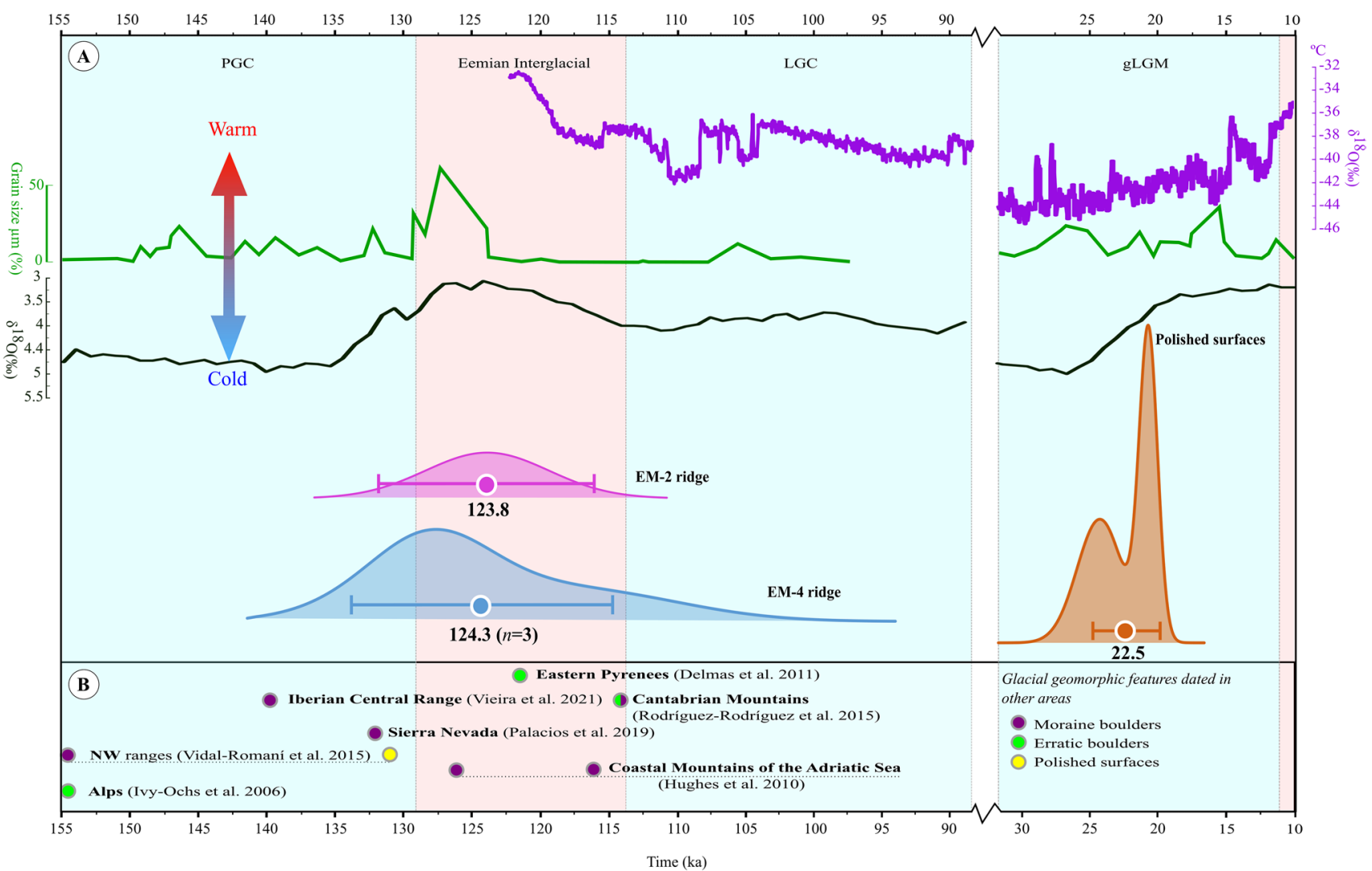

Fig. 7 Normalized probability distribution functions (PDF) of the ${ }^{10} \mathrm{Be}$ CRE exposure ages vs. A Temperature evolution from the MIS 6 to the gLGM based on the $\delta^{18} \mathrm{O}$ record from the NGRIP ice core from Greenland (time periods are defined after Rasmussen et al. (2014)); percentage of grain size $(>150 \mu \mathrm{m})$ per sample in ice-rafted debris
(IRD) from ocean sediments cores (McManus et al. 1999); benthic $\delta^{18} \mathrm{O}$ record from global distribution (Lisiecki and Raymo 2005); and B other CRE dated glacial landforms. The plots of the units result from the sum of the individual PDF of the samples belonging to them. Cold (warm) phases are represented by the blue (red) bands
No robust chronological data on glacial records have been obtained so far to confirm the MIS 6 glaciation in the Pyrenees. Indeed, the wide temporal range (170-120 ka) of exposure ages and associated uncertainties do not let us to have a clear idea about the maximum of the PGC in the Pyrenees. In any case, in this work, the first ${ }^{10} \mathrm{Be} \mathrm{CRE}$ data set from moraine boulders was introduced in Pyrenees that reveal the occurrence of a large glaciation during the MIS 6 in the Upper Garonne Valley. At that time, the ice covered the terminal basin and the glacial system was more extensive than during the ILGM advance. The onset of the penultimate deglaciation started at $129 \mathrm{ka}$, when the Garonne Glacier abandoned the two moraine ridges (EM-2 and EM-4) located at $480 \mathrm{~m}$ and they stabilized.

Intense postglacial geomorphic dynamics (glacial, periglacial, slope and alluvial) have eroded glacial landforms left by previous glaciations, and therefore, the glacial evidence from MIS 6 in the Pyrenees can be only found in a few valleys. The glacial deposits beyond the limits of the LGC in this mountain range have been only recently ascribed to the PGC and gradually confirmed by optically stimulated luminescence (OSL) and CRE dating techniques (Oliva et al. 2019). These deposits, which are highly degraded, presenting only few scattered boulders suitable to CRE dating, are normally located in flat areas far from slope, periglacial and alluvial processes. Several studies have been published showing the glacial and karst evidence from the PGC in the Pyrenees and interpreted from the MIS 6 (Delmas et al. 2011; García-Ruiz et al. 2013; Sorriaux et al. 2016). Within the uncertainties, these evidences are also supported by a fluvial aggradation episode at 178 and $151 \mathrm{ka}$ based on the existence of fluvial and fluvioglacial sediments in fluvial terraces of the Cinca and Gállego valleys, respectively (Lewis et al. 2009).

Available dates of glacial processes during the PGC elsewhere in the Iberian Peninsula are also scarce. Similarly to what has happened with the LGC (Oliva et al. 2019), the increasing application of CRE methods is showing that the most extensive glaciers developed at the end of the PGC. CRE ages between 140 and 120 ka have been reported in several mountain regions regarding the most external moraines. This is the case of Sierra Nevada, where the lowest moraine 
was dated at 130-135 ka; Serra da Estrela, where the highest right lateral moraine was developed by $\sim 140 \mathrm{ka}$; and even in the NW ranges, where a push moraine and a polished surface were dated at 155 and $131 \mathrm{ka}$ (Table 4).

Glacial evidence of the PGC has also been detected in other European mountains confirming the maximum glacial advance of the PGC during the MIS 6 . This pattern occurred in the Alps, where one erratic boulder in the Jura Mountains was dated using two cosmogenic nuclides, ${ }^{21} \mathrm{Ne}$ and ${ }^{10} \mathrm{Be}$, yielding 128 and $106 \mathrm{ka}$, respectively (Ivy-Ochs et al. 2006). In the Austrian Alps, OSL was applied to glaciofluvial, fluviolacustrine and eolian sediments showing a culmination of the PGC during the late MIS 6 (149-135 ka) (Bickel et al. 2015). Further south, very similar ages were obtained from U-series in the coastal mountains of the Adriatic Sea revealing cold conditions during the MIS 6, with moraine development starting at $125 \mathrm{ka}$ in the Bijela Gora plateau (Hughes et al. 2010) and at $131 \mathrm{ka}$ for the moraines from the Mount Tymphi, at the northern slope of the Pindus Mountains (Hughes et al. 2006).

During the gLGM, the terminal LBBb was ice free with the glaciers retreating towards headwaters at 24-21 ka. This is supported by exposures ages from polished surfaces, at $18 \mathrm{~km}$ southwards the EM-1 ridge, on the lower slopes of the Marignac overdeepened basin that became ice-free by that time (Fig. 7). Therefore, our results also introduce new chronological data about glacial dynamics occurring during the gLGM in the Central Pyrenees. In other valleys of this range, glaciers showed contrasting patterns of glacial advance or retreat during the gLGM. In the Eastern Pyrenees, a glacial advance occurred synchronous with the gLGM, that was noticed in the Têt Valley, where a moraine at 1,690 $\mathrm{m}$ was dated to $25 \mathrm{ka}$ (Tomkins et al. 2018); and in the La Llosa and Duran valleys, where moraines at $1520 \mathrm{~m}$ and at $1830 \mathrm{~m}$ were dated to 20 and $21 \mathrm{ka}$, respectively (Andrés et al. 2018). In the southern slope of the Pyrenees, glacial retreat was deduced in the upper sector of the Gállego Valley based on a paleolake located at $\sim 1500 \mathrm{~m}$ dammed by landslide by $20 \mathrm{ka}$ (García-Ruiz et al. 2003).

In the Iberian Peninsula, a general glacial advance occurred at 22-19 ka followed by a massive recession (Oliva et al. 2019). In the central and northern part of the Iberia, other valleys also recorded glacial advances, such as in the Iberian Range, where the end of the gLGM was recorded based on lacustrine sediments in the Sierra de Neila was recorded prior to $21 \mathrm{ka}$ (Vegas Salamanca 2007) or in NW ranges, where the glacier front in the Tera Valley also remained stable until 22 cal ka BP (Rodríguez-Rodríguez et al. 2011). In the southern Iberian Peninsula, glaciers advanced during the gLGM in the Serra Nevada, where moraine stabilization in the San Juan Valley occurred at 21-19 ka (Palacios et al. 2016). In other European mountains, such as the Alps (Ivy-Ochs et al. 2008) or the at the Tatra Mountains (Engel et al. 2015), glaciers reached their maximum position of the LGC at 26-21 ka and undergone a subsequence massive retreat afterwards, at 20-19 ka. This suggests that the Garonne Glacier was already retreating when $\mathrm{CO}_{2}$ concentrations in the atmosphere were still low (180-200 ppm; Shakun et al. 2015).

\section{Conclusions}

The Pyrenees hosted large ice fields during Quaternary glacial phases, with extensive alpine glaciers descending from the highest peaks of the axis of this mountain range. Those glaciers shaped the landscape and left a wide range of geomorphological features of glacial origin, both within the mountain range as well as in the surrounding lowlands of the northern slope. This is the case of the northern foreland of the Central Pyrenees at the LBBb. Here, the longest Late Pleistocene glacier in the Pyrenees that flowed northwards

Table 4 Comparison of the glacial chronology of the Penultimate Glaciation in the northern valleys of the Pyrenees

\begin{tabular}{|c|c|c|c|c|c|}
\hline Range & Valley & Age & Geomorphological unit & Dating method & Reference \\
\hline Pyrenees (Northern slope) & Ariège Valley & $122 \mathrm{ka}$ & $\begin{array}{l}\text { Erratic boulder lying on } \\
\text { bedrock }\end{array}$ & $\operatorname{CRE}\left({ }^{10} \mathrm{Be}\right)$ & Delmas et al. (2011) \\
\hline Pyrenees (Southern slope) & Aragón Valley & $171 \mathrm{ka}$ & Frontal moraine & OSL & García-Ruiz et al. (2013) \\
\hline $\begin{array}{l}\text { Central Range (Serra da } \\
\text { Estrela) }\end{array}$ & Zêzere Valley & $140 \mathrm{ka}$ & Lateral moraine & $\operatorname{CRE}\left({ }^{36} \mathrm{Cl}\right)$ & Vieira et al. (2021) \\
\hline Betic Range (Sierra Nevada) & Naute Valley & $130-135 \mathrm{ka}$ & Terminal moraine & $\mathrm{CRE}\left({ }^{10} \mathrm{Be}\right)$ & Palacios et al. (2019) \\
\hline Cantabrian Mountains & Porma Valley & $114 \mathrm{ka}$ & $\begin{array}{l}\text { Erratic boulders and ground } \\
\text { moraine at the terminal zone }\end{array}$ & $\mathrm{CRE}\left({ }^{10} \mathrm{Be}\right)$ & $\begin{array}{l}\text { Rodríguez-Rodríguez et al. } \\
\text { (2016) }\end{array}$ \\
\hline $\begin{array}{l}\text { NW ranges (Serra de Queixa- } \\
\text { Invernadoiro) }\end{array}$ & Conso Valley & $155 \mathrm{ka}$ & Push moraine boulder & $\mathrm{CRE}\left({ }^{21} \mathrm{Ne}\right)$ & Vidal-Romaní et al. (2015) \\
\hline NW ranges (Serra Gerês-Xurés) & $\begin{array}{l}\text { Portela da } \\
\text { Amoreira } \\
\text { divide }\end{array}$ & $131 \mathrm{ka}$ & Polished surface & $\mathrm{CRE}\left({ }^{21} \mathrm{Ne}\right)$ & Vidal-Romaní et al. (2015) \\
\hline
\end{tabular}


along $\sim 80 \mathrm{~km}$ formed a terminal moraine system at only $420 \mathrm{~m}$ on its terminal position.

We present a 10-sample data set of ${ }^{10} \mathrm{Be} C R E$ dating providing ages for the Late Quaternary maximum ice extent as well as the extent of the Garonne glacier at the time of the gLGM. The long time passed, since last deglaciation has favoured postglacial erosive processes and only a few stable boulders suitable for the application of CRE dating were found. Four boulders from the external moraine ridges confirm that the largest palaeoglacier in the Upper Garonne Valley developed before the LGC, at 129 ka. These are the first CRE ages reporting a period of glacial expansion in the Pyrenees during the PGC, as also observed in other Iberian mountain ranges (e.g., Sierra Nevada, Central Range, NW Ranges), where the largest glacial advance during the MIS 6 was followed by a period of moraine stabilization at $\sim 129 \mathrm{ka}$. However, boulders from the internal moraine system of the glacial terminal basin did not yield consistent geochronological results. Therefore, no data of glacial advance or retreat during the LGC is available in LBBb. Exposure ages from glacially polished bedrock surfaces located at the confluence Garonne-la Pique valleys- $18 \mathrm{~km}$ to the south of the external moraines-reported ages of 24-21 ka, confirming that the terminal basin was already ice-free during the gLGM.

A better understanding of glacial oscillations during glacial cycles prior to the last one is of major importance to assess whether the spatial and temporal trends of the last glaciation followed the same pattern observed in previous glaciations or they constitute a singular case during the Quaternary. Future research must provide further evidence of the occurrence of this glacial phase in the Pyrenees and couple it with environmental dynamics in the lowlands. The application of individual dating techniques does not resolve the full chronological sequence of the glacial oscillations during the PGC. Future research should address the combination of several data sources (fluvial, glacial, eolian, lacustrine, karst and archeological) and complement them with different chronological methods such as OSL and CRE dating to avoid the intrinsic limitations of each technique and circumvent the uncertainties associated with the occurrence of postglacial processes in such a dynamic environment.

Acknowledgements The authors sincerely thank the Dr. Ramón Pellitero for his help to the construction of the Garonne palaeoglacier. We also thank to anonymous reviewers for the constructive revision of an earlier draft of the manuscript. The authors are grateful to Dr. Augusto Pérez-Alberti for his guidance and wise advices during his prolific scientific career. ASTER Team: Georges Aumaître, Karim Keddadouche.

Author contributions MF Laboratory tasks (sample processing), collection and handling of aerial photo imagery, geomorphological mapping and writing of a first draft of the manuscript. MO Coordination of the research, funding acquisition, field work, geomorphological analysis, sampling, data processing and contributing to the writing and final revision of the manuscript. GV Geomorphological analysis, discussion of results, contribution to the writing and final revision of the manuscript. DP Fieldwork, geomorphological analysis, discussion of the results, and contribution to the writing and final revision of the manuscript. JMF-F Laboratory tasks (sample processing, exposure age calculations), contribution to the writing and final revision of the manuscript. MD Geomorphological analysis, discussion of results, contribution to the final revision of the manuscript. JG-O Laboratory tasks (sample processing, exposure age calculations), contribution to the writing and final revision of the manuscript. IS Supervision of the whole process of the sample processing and interpretation of the results, contribution to the writing and final revision of the manuscript. JV Fieldwork, geomorphological analysis, discussion of results, contribution to the writing and final revision. ASTER Team. Supervision of the AMS measurements of the ${ }^{36} \mathrm{Cl}$ samples.

Funding This research was financially supported by the Research Group ANTALP (Antarctic, Arctic, Alpine Environments; 2017SGR-1102) funded by the Government of Catalonia and the Centro de Estudos Geográficos/IGOT-University of Lisbon (FCT I.P. UIDB/00295/2020 and UIDP/00295/2020). The study topics complement those of the project PALEOGREEN (CTM2017-87976-P) funded by the Spanish Ministry of Economy and Competitiveness and the project NUNANTAR funded by the Fundação para a Ciência e Tecnologia of Portugal (02/SAICT/2017-32002). Marcelo Fernandes currently holds a PhD fellowship of the Fundação para a Ciência e Tecnologia of Portugal (FCT_SFRH/139569/2018); Marc Oliva is supported by the Ramón y Cajal Program (RYC-2015-17597) and José M. Fernández-Fernández is supported by a postdoctoral grant within the NUNANTAR project. ${ }^{10} \mathrm{Be}$ measurements were performed at the ASTER AMS national facility (CEREGE, Aix-en-Provence), which is supported by the INSU/CNRS and the ANR through the "Projets thématiques d'excellence" program for the "Equipements d'excellence" ASTER-CEREGE action and IRD. This work is also framed within the College on Polar and Extreme Environments (Polar2E) of the University of Lisbon.

Availability of data and materials The data presented in this article are openly available in this website: http://alpine.ice-d.org/

Code availability The geomorphological map was developed using ArcGIS 10.7.1 (ESRI) software based on the UTM projection and the ETRS 89 zone $31 \mathrm{~N}$ coordinate system. The layouts were improved with the Inkscape 1.0 software.

\section{Declarations}

Conflict of interest The authors declare that they have no known competing financial interests or personal relationships that could have appeared to influence the work reported in this paper.

Ethics approval Not applicable.

Consent to participate Not applicable.

Consent for publication Not applicable.

\section{References}

Adamson K, Hughes P, Woodward J (2013) Pleistocene glaciation of the Mediterranean Mountains. Quat Newsl 131:2-15 
Andrés N, Gómez-Ortiz A, Fernández-Fernández JM, Tanarro García LM, Salvador-Franch F, Oliva M, Palacios D (2018) Timing of deglaciation and rock glacier origin in the southeastern Pyrenees: a review and new data. Boreas 47:1050-1071. https://doi.org/10. 1111/bor.12324

Andrieu V (1987) Le paléoenvironnement du piémont nord-pyrénéen occidental de 27000 BP au Postglaciaire: la séquence d'Estarrès (Pyrénées Atlantiques, France) dans le bassin glaciaire d'Arudy. Comp Rend Acad Sci 304:103-108

Andrieu V (1991) Dynamique du paléoenvironnement de la vallée montagnarde de la Garonne (Pyrénées centrales, France) de la fin des temps glaciaires à l'actuel. Dissertation. Toulouse 2

Andrieu V, Hubschman J, Jalut G, Hérail G (1988) Chronologie de la dégladation des Pyrénées françaises. Dynamique de sédimentation et contenu pollinique des paléolacs ; application à l'interprétation du retrait glaciaire. Bull Assoc Fran Quat 25:55-67

Bakalowicz M, Sorriaux P, Ford D (1984) Quaternary glacial events in the Pyrenees from U-series dating of speleothems in the NiauxLombrives-Sabart caves, Ariège, France. Nor Geogr Tidsskr 38:193-197. https://doi.org/10.1080/00291958408552125

Benn DI, Evans DJA (2010) Glaciers and glaciation, 2nd edn. Hodder Education, London. https://doi.org/10.5860/CHOICE.35-6240

Benn DI, Hulton NRJ (2010) An Excel ${ }^{\mathrm{TM}}$ spreadsheet program for reconstructing the surface profile of former mountain glaciers and ice caps. Comput Geosci 36:605-610. https://doi.org/10.1016/j. cageo.2009.09.016

Bernal-Wormull JL, Moreno A, Bartolomé M, Aranburu A, Arriolabengoa M, Iriarte E, Cacho I, Spötl C, Edwards RL, Cheng H (2021) Immediate temperature response in northern Iberia to last deglacial changes in the North Atlantic. Geology XX. https://doi. org/10.1130/G48660.1

Bickel L, Lüthgens C, Lomax J, Fiebig M (2015) The timing of the penultimate glaciation in the northern Alpine Foreland: new insights from luminescence dating. Proc Geol Assoc 126:536550. https://doi.org/10.1016/j.pgeola.2015.08.002

Braucher R, Guillou V, Bourlès DL, Arnold M, Aumaître G, Keddadouche K, Nottoli E (2015) Preparation of ASTER in-house 10Be/9Be standard solutions. Nucl Instrum Methods Phys Res B Beam Interact Mater Atoms 361:335-340. https://doi.org/10. 1016/j.nimb.2015.06.012

Briner J, Kaufman D, Manley W, Finkel R, Caffee M (2005) Cosmogenic exposure dating of late Pleistocene moraine stabilization in Alaska. Geol Soc Am Bull 117:1108-1120. https://doi.org/10. 1130/B25649.1

Calvet M (1996) Morphogenèse d'une montagne méditerranéenne: Les Pyrénées Orientales. Dissertation. University of Orléans

Calvet M, Delmas M, Gunnell Y, Braucher R, Bourlès D (2011) Recent advances in research on quaternary glaciations in the pyrenees. Dev Quat Sci 15:127-139. https://doi.org/10.1016/B978-0-44453447-7.00011-8

Calvet M, Gunnell Y, Laumonier B (2021) Denudation history and palaeogeography of the Pyrenees and their peripheral basins: an 84-million-year geomorphological perspective. Earth Sci Rev 215:103436. https://doi.org/10.1016/j.earscirev.2020.103436

Campos N, Alcalá-Reygosa J, Watson S, Kougkoulos I, QuesadaRomán A, Grima N (2021) Modeling the retreat of the Aneto Glacier (Spanish Pyrenees) since the Little Ice Age, and its accelerated shrinkage over recent decades. Holocene 31:1315-1326. https://doi.org/10.1177/09596836211011678

Colleoni F, Wekerle C, Näslund JO, Brandefelt J, Masina S (2016) Constraint on the penultimate glacial maximum Northern Hemisphere ice topography ( $\approx 140$ kyrs BP). Quat Sci Rev 137:97-112. https://doi.org/10.1016/j.quascirev.2016.01.024

Copons R, Bordonau J (1996) El registro sedimentario del Cuaternario Reciente en el lago Redó d'Aigüestortes (Pirineos Centrales). In:
Grandal A, Pagés J (eds) IV Reunión de Geomorfología. Sociedad Española de Geomorfología

Crest Y, Delmas M, Braucher R, Gunnell Y, Calvet M (2017) Cirques have growth spurts during deglacial and interglacial periods: evidence from $10 \mathrm{Be}$ and $26 \mathrm{Al}$ nuclide inventories in the central and eastern Pyrenees. Geomorphology 278:60-77. https://doi.org/10. 1016/j.geomorph.2016.10.035

Dahl-Jensen D, Albert MR, Aldahan A, Azuma N, Balslev-Clausen $\mathrm{D}$, Baumgartner M, Berggren AM, Bigler M, Binder T, Blunier T, Bourgeois JC, Brook EJ, Buchardt SL, Buizert C, Capron E, Chappellaz J, Chung J, Clausen HB, Cvijanovic I, Davies SM, Ditlevsen P, Eicher O, Fischer H, Fisher DA, Fleet LG, Gfeller G, Gkinis V, Gogineni S, Goto-Azuma K, Grinsted A, Gudlaugsdottir H, Guillevic M, Hansen SB, Hansson M, Hirabayashi M, Hong S, Hur SD, Huybrechts P, Hvidberg CS, Iizuka Y, Jenk T, Johnsen SJ, Jones TR, Jouzel J, Karlsson NB, Kawamura K, Keegan K, Kettner E, Kipfstuhl S, Kjær HA, Koutnik M, Kuramoto T, Köhler P, Laepple T, Landais A, Langen PL, Larsen LB, Leuenberger D, Leuenberger M, Leuschen C, Li J, Lipenkov V, Martinerie P, Maselli OJ, Masson-Delmotte V, McConnell JR, Miller H, Mini O, Miyamoto A, Montagnat-Rentier M, Mulvaney R, Muscheler R, Orsi AJ, Paden J, Panton C, Pattyn F, Petit JR, Pol K, Popp T, Possnert G, Prié F, Prokopiou M, Quiquet A, Rasmussen SO, Raynaud D, Ren J, Reutenauer C, Ritz C, Röckmann T, Rosen JL, Rubino M, Rybak O, Samyn D, Sapart CJ, Schilt A, Schmidt AMZ, Schwander J, Schüpbach S, Seierstad I, Severinghaus JP, Sheldon S, Simonsen SB, Sjolte J, Solgaard AM, Sowers T, Sperlich P, Steen-Larsen HC, Steffen K, Steffensen JP, Steinhage D, Stocker TF, Stowasser C, Sturevik AS, Sturges WT, Sveinbjörnsdottir A, Svensson A, Tison JL, Uetake J, Vallelonga P, Van De Wal RSW, Van Der Wel G, Vaughn BH, Vinther B, Waddington E, Wegner A, Weikusat I, White JWC, Wilhelms F, Winstrup M, Witrant E, Wolff EW, Xiao C, Zheng J (2013) Eemian interglacial reconstructed from a Greenland folded ice core. Nature 493:489-494. https://doi.org/10.1038/nature11789

Delmas M, Gunnell Y, Braucher R, Calvet M, Bourlès D (2008) Exposure age chronology of the last glaciation in the eastern Pyrenees. Quat Res 69:231-241. https://doi.org/10.1016/j.yqres.2007.11. 004

Delmas M, Calvet M, Gunnell Y, Braucher R, Bourlès D (2011) Palaeogeography and 10Be exposure-age chronology of Middle and Late Pleistocene glacier systems in the northern Pyrenees: implications for reconstructing regional palaeoclimates. Palaeogeogr Palaeoclimatol Palaeoecol 305:109-122. https://doi.org/10.1016/j. palaeo.2011.02.025

Delmas M, Braucher R, Gunnell Y, Guillou V, Calvet M, Bourlès D (2015) Constraints on Pleistocene glaciofluvial terrace age and related soil chronosequence features from vertical ${ }^{10} \mathrm{Be}$ profiles in the Ariège River catchment (Pyrenees, France). Glob Planet Change 132:39-53. https://doi.org/10.1016/j.gloplacha.2015.06. 011

Delmas M, Calvet M, Gunnell Y, Voinchet P, Manel C, Braucher R, Tissoux H, Bahain JJ, Perrenoud C, Saos T (2018) Terrestrial ${ }^{10} \mathrm{Be}$ and electron spin resonance dating of fluvial terraces quantifies quaternary tectonic uplift gradients in the eastern Pyrenees. Quat Sci Rev 193:188-211. https://doi.org/10.1016/j.quascirev.2018. 06.001

Delmas M, Gunnell Y, Calvet M, Reixach T, Oliva M (2021a) The Pyrenees: glacial landforms prior to the Last Glacial Maximum. In: Palacios D, Hughes P, García-Ruiz JM, Andrés N (eds) European glacial landscapes: maximum extent of glaciations. Elsevier, Amsterdam

Delmas M, Gunnell Y, Calvet M, Reixach T, Oliva M (2021b) The Pyrenees: glacial landforms from the Last Glacial maximum. In: Palacios D, Hughes P, García-Ruiz JM, Andrés N (eds) European 
glacial landscapes: maximum extent of glaciations. Elsevier, Amsterdam

Ehlers J, Gibbard PL, Hughes PD (2011) Quaternary glaciationsextent and chronology: a closer look. In: Developments in quaternary science, vol 15. Elsevier, Amsterdam

Engel Z, Mentlík P, Baucher R, Minár J, Léanni L, Aster Team (2015) Geomorphological evidence and ${ }^{10} \mathrm{Be}$ exposure ages for the last glacial maximum and deglaciation of the Velká and Malá Studená dolina valleys in the High Tatra Mountains, central Europe. Quat Sci Rev 124:106-123. https://doi.org/10.1016/j.quascirev.2015. 07.015

Fernandes M, Oliva M, Palma P, Ruiz-Fernández J, Lopes L (2017) Glacial stages and post-glacial environmental evolution in the Upper Garonne valley, Central Pyrenees. Sci Total Environ 584585:1282-1299. https://doi.org/10.1016/j.scitotenv.2017.01.209

Fernandes M, Oliva M, Vieira G, Palacios D, Fernández-Fernández JM, Garcia-Oteyza J, Schimmelpfennig I, ASTER Team, Antoniades D (2021) Glacial oscillations during the Bølling-Allerød Interstadial-Younger Dryas transition in the Ruda Valley. J Quat Sci, Central Pyrenees. https://doi.org/10.1002/jqs.3379

Gangloff P, Hetu B, Courchesne F (1991) Présence d'un dépôt glaciaire sous la terrasse moyenne d'Agnos, vallée d'Aspe (PyrénéesAtlantiques). Quaternaire 2:131-133. https://doi.org/10.3406/ quate.1991.1962

García-Ruiz JM, Valero-Garcés BL, Martí-Bono C, González-Sampériz $\mathrm{P}$ (2003) Asynchroneity of maximum glacier advances in the central Spanish Pyrenees. J Quat Sci 18:61-72. https://doi. org/10.1002/jqs.715

García-Ruiz JM, Martí-Bono C, Peña-Monné J, Sancho C, Rhodes E, Valero-Garcés BL, González-Sampériz P, Moreno A (2013) Glacial and fluvial deposits in the Aragón Valley, Central-Western Pyrenees: chronology of the Pyrenean Late Pleistocene Glaciers. Geogr Ann Ser A Phys Geogr 95:15-32. https://doi.org/10.1111/j. 1468-0459.2012.00478.x

González-Sampériz P, Valero-Garcés BL, Moreno A, Jalut G, GarcíaRuiz JM, Martí-Bono C, Delgado-Huertas A, Navas A, Otto T, Dedoubat J (2006) Climate variability in the Spanish Pyrenees during the last 30,000 yr revealed by the El Portalet sequence. Quat Res 66:38-52. https://doi.org/10.1016/j.yqres.2006.02.004

Gosse J, Philips F (2001) Terrestrial in situ cosmogenic nuclides: theory and application. Quat Sci Rev 20:1475-1560. https://doi.org/ 10.1016/S0277-3791(00)00171-2

Gourinard Y (1971) Les moraines de la basse vallée du Carol entre Latour et Puicerda (Pyrénées orientales franco-espagnoles). Comp Rend Acad Sci 272:3112-3115

Grant KM, Rohling EJ, Bronk Ramsey C, Cheng H, Edwards RL, Florindo F, Heslop D, Marra F, Roberts AP, Tamisiea ME, Williams F (2014) Sea-level variability over five glacial cycles. Nat Commun. https://doi.org/10.1038/ncomms6076

Hearty PJ, Hollin JT, Neumann AC, O'Leary MJ, McCulloch M (2007) Global sea-level fluctuations during the last interglaciation (MIS 5e). Quat Sci Rev 26:2090-2112. https://doi.org/10.1016/j.quasc irev.2007.06.019

Hétu B, Gangloff P (1989) Dépôts glaciaires du Pléistocène inférieur sur le piémont des Pyrénées Atlantiques. Zeitschr Geomorphol 33:384-403

Hétu B, Gangloff P, Courchesne F (1992) Un till de déformation du Pléistocène inférieur à la basé de la Formation du Lannemezan (Piémont des Pyrénées Atlantiques, France). Quaternaire 3:53-61

Hubschman J (1975) Conclusion : evolution pédo-géochimique et interprétation paléobioclimatique de piémont quaternaire garonnais. Bull Assoc Fran Quat 12:211-216

Hubschman J (1984) Glaciaire ancien et glaciaire récent: analyse comparée de l'altération de moraines terminals nord-pyrénéennes. Mont Piémonts RGPSO, pp 313-332
Hughes PD, Woodward JC, Gibbard PL, Macklin MG, Gilmour MA, Smith GR (2006) The glacial history of the Pindus Mountains, Greece. J Geol 114:413-434. https://doi.org/10.1086/504177

Hughes P, Woodward JC, van Calsteren PC, Thomas AL, Adamson KR (2010) Pleistocene ice caps on the coastal mountains of the Adriatic Sea. Quat Sci Rev 29:3690-3708. https://doi.org/10.1016/j. quascirev.2010.06.032

ICGC (2017) Base de dades geològiques de Catalunya 1:50.000 v1.0

Ivy-Ochs S, Kerschner H, Reuther A, Maisch M, Sailer R, Schaefer J, Kubik PW, Synal H, Schlüchter C (2006) The timing of glacier advances in the northern European Alps based on surface exposure dating with cosmogenic $10 \mathrm{Be}, 26 \mathrm{Al}, 36 \mathrm{Cl}$, and $21 \mathrm{Ne}$. Geol Soc Am Spec Pap 415:43-60. https://doi.org/10.1130/2006. 2415(04)

Ivy-Ochs S, Kerschner H, Reuther A, Preusser F, Heine K, Maisch M, Kubik P, Schluchter C (2008) Chronology of the last glacial cycle in the European Alps. J Quat Sci 22:559-573. https://doi. org/10.1002/jqs.1202

Jalut G, Delibrias G, Dagnac J, Mardones M, Bouhours M (1982) A palaeoecological approach to the last 21000 years in the pyrenees: the peat bog of Freychinède (Alt. 1350 m, Ariège, South France). Palaeogeogr Palaeoclimatol Palaeoecol 40:321-359. https://doi. org/10.1016/0031-0182(82)90033-5

Jalut G, Andrieu V, Delibrias G, Fontugne M (1988) Palaeoenvironment of the valley of Ossau (Western French Pyrenees) during the last 27,000 years. Pollen Spores 30:357-394

Jalut G, Monserrat-Marti J, Fontugne M, Delibrian G, Vilaplana J, Rosen J (1992) Glacial to interglacial vegetation changes in the northern and southern Pyrénées: deglaciation, vegetation cover and chronology. Quat Sci Rev 11:449-480

Jones RS, Small D, Cahill N, Bentley MJ, Whitehouse PL (2019) iceTEA: tools for plotting and analysing cosmogenic-nuclide surface-exposure data from former ice margins. Quat Geochronol 51:72-86. https://doi.org/10.1016/j.quageo.2019.01.001

Lewis CJ, McDonald EV, Sancho C, Peña JL, Rhodes EJ (2009) Climatic implications of correlated Upper Pleistocene glacial and fluvial deposits on the Cinca and Gállego Rivers (NE Spain) based on OSL dating and soil stratigraphy. Glob Planet Change 67:141152. https://doi.org/10.1016/j.gloplacha.2009.01.001

Li Y (2018) Determining topographic shielding from digital elevation models for cosmogenic nuclide analysis: a GIS model for discrete sample sites. J Mt Sci 15:939-947. https://doi.org/10.1007/ s11629-018-4895-4

Lifton N, Sato T, Dunai T (2014) Scaling in situ cosmogenic nuclide production rates using analytical approximations to atmospheric cosmic-ray fluxes. Earth Planet Sci Lett 386:149-160. https://doi. org/10.1016/j.epsl.2013.10.052

Lisiecki L, Raymo M (2005) A Pliocene-Pleistocene stack of 57 globally distributed benthic $\delta 180$ records. Paleoceanography 20:1-7. https://doi.org/10.1029/2004PA001071

Mardones M, Jalut G (1983) La tourbiere de Biscaye (alt. 409 m, Hautes Pyrenees): approche paleoecologique des 45.000 dernières annees. Pollen Spores 25:163-212

Martin LCP, Blard PH, Balco G, Lavé J, Delunel R, Lifton N, Laurent V (2017) The CREp program and the ICE-D production rate calibration database: a fully parameterizable and updated online tool to compute cosmic-ray exposure ages. Quat Geochronol 38:25-49. https://doi.org/10.1016/J.QUAGEO.2016.11.006

Martrat B, Grimalt JO, Shackleton NJ, De Abreu L, Hutterli MA, Stocker TF (2007) Four climate cycles of recurring deep and surface water destabilizations on the Iberian margin. Science 317:502-507. https://doi.org/10.1126/science.1139994

McManus JF, Oppo DW, Cullen JL (1999) A 0.5-Million-year record of millennial-scale climate variability in the North Atlantic. Science 283:971-975. https://doi.org/10.1126/science.283.5404.971 
Menviel L, Capron E, Govin A, Dutton A, Tarasov L, Abe-Ouchi A, Drysdale RN, Gibbard PL, Gregoire L, He F, Ivanovic RF, Kageyama M, Kawamura K, Landais A, Otto-Bliesner BL, Oyabu I, Tzedakis PC, Wolff E, Zhang X (2019) The penultimate deglaciation: protocol for paleoclimate modelling intercomparison project (PMIP) phase 4 transient numerical simulations between 140 and $127 \mathrm{ka}$, version 1.0. Geosci Model Dev 12:3649-3685. https://doi.org/10.5194/gmd-12-3649-2019

Merchel S, Herpers U (1999) An update on radiochemical separation techniques for the determination of long-lived radionuclides via accelerator mass spectrometry. Radiochim Acta 84:215-219. https://doi.org/10.1524/ract.1999.84.4.215

Merchel S, Arnold M, Aumaître G, Benedetti L, Bourlès DL, Braucher R, Alfimov V, Freeman SPHT, Steier P, Wallner A (2008) Towards more precise $10 \mathrm{Be}$ and $36 \mathrm{Cl}$ data from measurements at the 10-14 level: influence of sample preparation. Nucl Instrum Methods Phys Res B 266:4921-4926. https://doi. org/10.1016/j.nimb.2008.07.031

Montserrat J (1992) Evolución glaciar y postglaciar del clima y la vegetación en la vertiente sur del Pirineo: estudio palinológico. Monogr. del Inst. Piren. Ecol. Actas. Instituto Pirenaico de Ecología

Morellón M, Valero-Garcés B, Vegas-Vilarrúbia T, González-Sampériz P, Romero Ó, Delgado-Huertas A, Mata P, Moreno A, Rico M, Corella JP (2009) Lateglacial and Holocene palaeohydrology in the western Mediterranean region: the Lake Estanya record (NE Spain). Quat Sci Rev 28:2582-2599. https://doi.org/10.1016/j. quascirev.2009.05.014

Obrochta S, Crowley T, Channell J, Hodell D, Baker P, Seki A, Yokoyama Y (2014) Climate variability and ice-sheet dynamics during the last three glaciations. Earth Planet Sci Lett 406:198-212. https://doi.org/10.1016/j.epsl.2014.09.004

Oliva M, Palacios D, Fernández-Fernández JM, Rodríguez-Rodríguez L, García-Ruiz JM, Andrés N, Carrasco RM, Pedraza J, PérezAlberti A, Valcárcel M, Hughes P (2019) Late quaternary glacial phases in the Iberian Peninsula. Earth Sci Rev 192:564-600. https://doi.org/10.1016/j.earscirev.2019.03.015

Oliva M, Fernandes M, Palacios D, Fernández-Fernández JM, Schimmelpfennig I, Team ASTER, Antoniades D (2021) Rapid deglaciation during the Bølling-Allerød Interstadial in the Central Pyrenees and associated glacial and periglacial landforms. Geomorphology. https://doi.org/10.1016/j.geomorph.2021.107735

Osmaston H (2005) Estimates of glacier equilibrium line altitudes by the area $\times$ altitude, the area $\times$ altitude balance ratio and the area $\times$ altitude balance index methods and their validation. Quat Int 138-139:22-31. https://doi.org/10.1016/j.quaint.2005.02.004

Palacios D, Andrés N, López-Moreno JI, García-Ruiz JM (2015a) Late Pleistocene deglaciation in the upper Gállego Valley, central Pyrenees. Quat Res (USA) 83:397-414. https://doi.org/10.1016/j. yqres.2015.01.010

Palacios D, Gómez-Ortiz A, Andrés N, Vázquez-Selem L, SalvadorFranch F, Oliva M (2015b) Maximum extent of Late Pleistocene glaciers and last deglaciation of La Cerdanya mountains, Southeastern Pyrenees. Geomorphology 231:116-129. https://doi.org/ 10.1016/j.geomorph.2014.10.037

Palacios D, Gómez-Ortiz A, Andrés N, Salvador-Franch F, Oliva M (2016) Timing and new geomorphologic evidence of the last deglaciation stages in Sierra Nevada (southern Spain). Quat Sci Rev 150:110-129. https://doi.org/10.1016/j.quascirev.2016.08. 012

Palacios D, García-Ruiz JM, Andrés N, Schimmelpfennig I, Campos N, Léanni L, Aumaître G, Bourlès DL, Keddadouche K (2017) Deglaciation in the central Pyrenees during the PleistoceneHolocene transition: timing and geomorphological significance. Quat Sci Rev 162:111-127. https://doi.org/10.1016/j.quascirev. 2017.03.007
Pallàs R, Rodés Á, Braucher R, Carcaillet J, Ortuño M, Bordonau J, Bourlès D, Vilaplana JM, Masana E, Santanach P (2006) Late Pleistocene and Holocene glaciation in the Pyrenees: a critical review and new evidence from 10Be exposure ages, south-central Pyrenees. Quat Sci Rev 25:2937-2963. https://doi.org/10.1016/j. quascirev.2006.04.004

Pallàs R, Rodés Á, Braucher R, Bourlès D, Delmas M, Calvet M, Gunnell Y (2010) Small, isolated glacial catchments as priority targets for cosmogenic surface exposure dating of Pleistocene climate fluctuations, southeastern Pyrenees. Geology 38:891-894. https:// doi.org/10.1130/G31164.1

Paterson WSB (1994) The physics of glaciers, 3rd edn. Elsevier, London

Pearce D, Ely J, Barr I, Boston C (2017) Glacier reconstruction. In: Cook S, Clarke L, Nield J (eds) Geomorphological techniques. British Society for Geomorphology, UK

Pellitero R, Rea BR, Spagnolo M, Bakke J, Hughes P, Ivy-Ochs S, Lukas S, Ribolini A (2015) A GIS tool for automatic calculation of glacier equilibrium-line altitudes. Comput Geosci 82:55-62. https://doi.org/10.1016/j.cageo.2015.05.005

Pellitero R, Rea BR, Spagnolo M, Bakke J, Ivy-Ochs S, Frew CR, Hughes P, Ribolini A, Lukas S, Renssen H (2016) GlaRe, a GIS tool to reconstruct the 3D surface of palaeoglaciers. Comput Geosci 94:77-85. https://doi.org/10.1016/j.cageo.2016.06.008

Porter SC (1975) Equilibrium-line altitudes of late Quaternary glaciers in the Southern Alps, New Zealand. Quat Res 5:27-47. https://doi. org/10.1016/0033-5894(75)90047-2

Quesada C, Oliveira J (2019) The geology of Iberia: a geodynamic approach. In: The Variscan cycle

Quinif Y, Maire R (1998) Pleistocene deposits in Pierre Saint-Martin cave, French Pyrenees. Quat Res 49:37-50. https://doi.org/10. 1006/qres.1997.1939

Rasmussen SO, Bigler M, Blockley SP, Blunier T, Buchardt SL, Clausen HB, Cvijanovic I, Dahl-Jensen D, Johnsen SJ, Fischer H, Gkinis V, Guillevic M, Hoek WZ, Lowe JJ, Pedro JB, Popp T, Seierstad IK, Steffensen JP, Svensson AM, Vallelonga P, Vinther BM, Walker MJC, Wheatley JJ, Winstrup M (2014) A stratigraphic framework for abrupt climatic changes during the Last Glacial period based on three synchronized Greenland ice-core records: Refining and extending the INTIMATE event stratigraphy. Quat Sci Rev 106:14-28. https://doi.org/10.1016/j.quascirev. 2014.09.007

Reille M, Andrieu V (1995) The late Pleistocene and Holocene in the Lourdes Basin, Western Pyrenees, France: new pollen analytical and chronology data. Veg Hist Archaeobot 4:1-21

Reixach T, Delmas M, Calvet M (2021) Climatic conditions between 19 and $12 \mathrm{ka}$ in the eastern Pyrenees, and wider implications for atmospheric circulation patterns in Europe. Quat Sci Rev. https:// doi.org/10.1016/j.quascirev.2021.106923

Rodríguez-Rodríguez L, Jiménez-Sánchez M, Domínguez-Cuesta MJ, Rico MT, Valero-Garcés B (2011) Last deglaciation in northwestern Spain: new chronological and geomorphologic evidence from the Sanabria region. Geomorphology 135:48-65. https://doi.org/ 10.1016/j.geomorph.2011.07.025

Sánchez-Goñi MF, Loutre MF, Crucifix M, Peyron O, Santos L, Duprat J, Malaizé B, Turon JL, Peypouquet JP (2005) Increasing vegetation and climate gradient in Western Europe over the Last Glacial Inception (122-110 ka): data-model comparison. Earth Planet Sci Lett 231:111-130. https://doi.org/10.1016/j.eps1.2004.12.010

Sancho C, Arenas C, Pardo G, Peña-Monné JL, Rhodes EJ, Bartolomé M, García-Ruiz JM, Martí-Bono C (2018) Glaciolacustrine deposits formed in an ice-dammed tributary valley in the south-central Pyrenees: new evidence for late Pleistocene climate. Sediment Geol 366:47-66. https://doi.org/10.1016/j.sedgeo.2018.01.008

Shakun JD, Clark PU, He F, Lifton NA, Liu Z, Otto-Bliesner BL (2015) Regional and global forcing of glacier retreat during the 
last deglaciation. Nat Commun 6:1-7. https://doi.org/10.1038/ ncomms 9059

Sorriaux P, Delmas M, Calvet M, Gunnell Y, Durand N, Edwige P (2016) Relations entre karst et glaciers depuis 450 ka dans les grottes de Niaux-Lombrives-Sabart (Pyrénées ariégeoises) Nouvelles datations U/Th dans la grotte de Niaux. Karstologia 67:3-16

Stange KM, van Balen RT, Kasse C, Vandenberghe J, Carcaillet J (2014) Linking morphology across the glaciofluvial interface: a $10 \mathrm{Be}$ supported chronology of glacier advances and terrace formation in the Garonne River, northern Pyrenees, France. Geomorphology 207:71-95. https://doi.org/10.1016/j.geomorph.2013. 10.028

Tomkins MD, Dortch JM, Hughes PD, Huck JJ, Stimson AG, Delmas M, Calvet M, Pallàs R (2018) Rapid age assessment of glacial landforms in the Pyrenees using Schmidt hammer exposure dating (SHED). Quat Res (US) 90:26-37. https://doi.org/10.1017/ qua.2018.12

Turu V, Peña-Monné JL (2006) Las terrazas fluviales del sistema SegreValira (Andorra-La Seu d'Urgell-Organyà, Pirineos Orientales): relación con el glaciarismo y la tectónica activa. Geomorfol. y Territ, pp 113-128

Turu V, Boulton GS, Ros I, Visus X, Peña-Monné JL, Martí-Bono C, Ibern JBI, Serrano-Cañadas E, Sancho-Marcén C, ConstanteOrrios A, Pous Fàbregas J, Gonzalez-Trueba JJ, Palomar Molins J, Herrero Simón R, García-Ruiz JM (2007) Structure des grands bassins glaciaires dans le nord de la péninsule ibérique : comparaison entre les vallées d'Andorre (Pyrénées orientales), du Gallego (Pyrénées centrales) et du Trueba (Chaîne cantabrique). Quaternaire. https://doi.org/10.4000/quaternaire.1167

Turu V, Calvet M, Bordonau J, Gunnell Y, Delmas M, Vilaplana J, Jalut G (2016) Did Pyrenean glaciers dance to the beat of global climatic events? Evidence from the Würmian sequence stratigraphy of an ice-dammed palaeolake depocentre in Andorra. Geol Soc Lond Spec Publ 433:111-136. https://doi.org/10.1144/sp433.6
Uppala SM, Kållberg PW, Simmons AJ, Andrae U, da Costa BV, Fiorino M, Gibson JK, Haseler J, Hernandez A, Kelly GA, Li X, Onogi K, Saarinen S, Sokka N, Allan RP, Andersson E, Arpe K, Balmaseda MA, Beljaars ACM, van de Berg L, Bidlot J, Bormann N, Caires S, Chevallier F, Dethof A, Dragosavac M, Fisher M, Fuentes M, Hagemann S, Hólm E, Hoskins BJ, Isaksen L, Janssen PAEM, Jenne R, McNally AP, Mahfouf JF, Morcrette JJ, Rayner NA, Saunders RW, Simon P, Sterl A, Trenberth KE, Untch A, Vasiljevic D, Viterbo P, Woollen J (2005) The ERA-40 re-analysis. Q J R Meteorol Soc 131:2961-3012. https://doi.org/ 10.1256/qj.04.176

Van der Veen C (1999) Fundamentals of glaciers dynamics, 2nd edn. Balkema, Rotterdam

Vegas Salamanca J (2007) Caracterización de eventos climáticos del Pleistoceno superior-Holoceno mediante el estudio sedimentológico de la Laguna Grande (Sierra Neila, NO Sistema Ibérico). Rev Soc Geol Esp 20:53-70

Wekerle C, Colleoni F, Näslund JO, Brandefelt J, Masina S (2016) Numerical reconstructions of the penultimate glacial maximum Northern Hemisphere ice sheets: Sensitivity to climate forcing and model parameters. J Glaciol 62:607-622. https://doi.org/10. 1017/jog.2016.45

Winograd IJ, Coplen TB, Landwehr JM, Riggs AC, Ludwig KR, Szabo BJ, Kolesar PT, Revesz KM (1992) Continuous 500,000-year climate record from vein calcite in Devils Hole, Nevada. Science 258:255-260. https://doi.org/10.1126/science.258.5080.255

Publisher's Note Springer Nature remains neutral with regard to jurisdictional claims in published maps and institutional affiliations. 